OECDpublishing

THE RETURN ON HUMAN (STEM) CAPITAL IN BELGIUM

GERT BIJNENS

EMMANUEL DHYNE

OECD PRODUCTIVITY WORKING PAPERS

July 2021 No. 26 


\section{OECD PRODUCTIVITY WORKING PAPERS}

The OECD Productivity Working Papers are associated with the Global Forum on Productivity that provides a forum for mutual exchange of information and fosters international co-operation between public bodies with responsibility for promoting productivity-enhancing policies, including in undertaking joint policy analysis. It offers a platform for exchanging views, experiences and information, institutional and governance arrangements and government structures, with a view towards developing better policies. The Forum extends existing work in the OECD through a well-prioritised and coherent stream of analytical work serving the policy research needs of participants on the drivers of productivity growth.

This paper has been authorised for publication by Luiz de Mello, Director, Policy Studies Branch, Economics Department, Álvaro Santos Pereira, Director, Country Studies Branch, Economics Department, and Andrew Wyckoff, Director, Directorate for Science, Technology and Innovation.

OECD Productivity Working Papers should not be reported as representing the official views of the OECD or of its member countries. The opinions expressed and arguments employed are those of the author(s).

Comments on OECD Productivity Working Papers are welcome and may be sent to: productivity@oecd.org OECD Productivity Working Papers are published on: oe.cd/productivity

Series: OECD Productivity Working Paper Series

ISSN 2413-9424

Please cite this paper as:

Bijnens, G., and Dhyne, E., "The return on human (STEM) capital in Belgium", OECD Productivity Working Papers, 2021 26, OECD Publishing, Paris.

This document and any map included herein are without prejudice to the status of or sovereignty over any territory, to the delimitation of international frontiers and boundaries and to the name of any territory, city or area.

The statistical data for Israel are supplied by and under the responsibility of the relevant Israeli authorities. The use of such data by the OECD is without prejudice to the status of the Golan Heights, East Jerusalem and Israeli settlements in the West Bank under the terms of international law.

(C) OECD (2021)

You can copy, download or print OECD content for your own use, and you can include excerpts from OECD publications, databases and multimedia products in your own documents, presentations, blogs, websites and teaching materials, provided that suitable acknowledgment of OECD as source and copyright owner is given. All requests for commercial use and translation rights should be submitted to PubRights@oecd.org. 


\section{ABSTRACT/RÉSUMÉ}

\section{The return on human (STEM) capital in Belgium}

Whilst overall productivity growth is stalling, firms at the frontier are still able to capture the benefits of the newest technologies and business practices. This paper uses linked employer-employee data covering all Belgian firms over a period of almost 20 years and investigates the differences in human capital between highly productive firms and less productive firms. We find a clear positive correlation between the share of high-skilled and STEM workers in a firm's workforce and its productivity. We obtain elasticities of 0.20 to 0.70 for a firm's productivity as a function of the share of high-skilled workers. For STEM (science, technology, engineering, mathematics) workers, of all skill levels, we find elasticities of 0.20 to 0.45 . More importantly, the elasticity of STEM workers is increasing over time, whereas the elasticity of high-skilled workers is decreasing. This is possibly linked with the increasing number of tertiary education graduates and at the same time increased difficulties in filling STEM-related vacancies. Specifically, for high-skilled STEM workers in the manufacturing sector, the productivity gain can be as much as 4 times higher than the gain from hiring additional high-skilled non-STEM workers. To ensure that government efforts to increase the adoption of the latest technologies and business practices within firms lead to sustainable productivity gains, such actions should be accompanied by measures to increase the supply and mobility of human (STEM) capital. Without a proper supply of skills, firms will not be able to reap the full benefits of the digital revolution.

JEL classification: E24, I26, J24.

Keywords: human capital, skills, education, productivity, linked employer-employee data.

\section{Le rendement du capital humain (STEM) en Belgique}

Alors que la croissance globale de la productivité stagne, les entreprises situées à la frontière sont toujours en mesure de tirer profit des technologies et des pratiques managériales les plus récentes. Ce papier utilise des données reliant employeurs et employés et couvrant toutes les entreprises belges sur une période de près de 20 ans. On étudie les différences en matière de capital humain entre les entreprises hautement productives et les entreprises qui le sont moins. Nous trouvons une corrélation positive claire entre la part de travailleurs hautement qualifiés ou qualifiés en STEM (sciences, technologie, ingénieur, mathématiques) dans la main-d'œuvre d'une entreprise et sa productivité. Nous obtenons des élasticités de 0.20 à 0.70 pour la productivité d'une entreprise en fonction de la part de travailleurs hautement qualifiés. Pour les travailleurs STEM (tous niveaux de qualification confondus), nous trouvons des élasticités de 0.20 à 0.45 . Plus important encore, l'élasticité des travailleurs STEM augmente au fil du temps, tandis que l'élasticité des travailleurs hautement qualifiés diminue. Ce phénomène est peut-être lié à l'augmentation du nombre de diplômés de l'enseignement supérieur et, parallèlement, aux difficultés accrues à pourvoir les postes vacants liés aux STEM. Plus précisément, pour les travailleurs STEM hautement qualifiés dans le secteur manufacturier, le gain de productivité peut être jusqu'à quatre fois plus élevé que le gain résultant de l'embauche de travailleurs non STEM hautement qualifiés supplémentaires. Pour s'assurer que les efforts des gouvernements visant à accroître l'adoption des dernières technologies et pratiques managériales au sein des entreprises conduisent à des gains de productivité durables, ces actions doivent être accompagnées de mesures visant à accroître l'offre et la mobilité du capital humain (STEM). Sans une offre adéquate de compétences, les entreprises ne seront pas en mesure de tirer pleinement parti de la révolution numérique.

Classification JEL: E24, I26, J24.

Mots-clés: capital humain, compétences, éducation, productivité, données reliant employeurs et employés. 


\section{Table of contents}

The return on human (STEM) capital in Belgium 6

1. Introduction 6

3. Descriptive evidence 13

4. Empirical findings $\quad 22$

5. Discussion and Conclusion $\quad 27$

References 29

$\begin{array}{ll}\text { Annex A. Industry classification } & 31\end{array}$

\section{Tables}

Table 1. Summary of main data statistics

Table 2. Human capital and productivity, regression results 24

Table 3. STEM human capital and productivity, regression results $\quad 27$

Table A.1. Mapping of NACE 2-digit industries into different classifications 31

\section{Figures}

Figure 1. Trend in labour productivity $\quad 7$

Figure 2. (STEM) tertiary education graduates 9

Figure 3. Firms and ICT recruiting 10

Figure 4. The share of early leavers from education 11

Figure 5. Share of foreigners in the workforce 12

Figure 6. The productivity gap for a medium performer a laggard compared to a frontier firm 16

Figure 7. Skill profile of a typical firm for different productivity groups 17

Figure 8. The gap for high-skilled workers (difference in share of high-skilled workers) in a medium performer and a laggard compared to a frontier firm 18

Figure 9. STEM skill profile of a typical firm in different productivity groups 19

Figure 10. The gap for high-skilled STEM workers (difference in share of high-skilled STEM workers) of a medium performer and a laggard compared to a frontier firm 20

Figure 11. The productivity gap and high-skilled STEM gap of a medium performer and a laggard compared to a frontier firm for ICT-intensive and non-ICT-intensive sectors 21

Figure 12. Foreigners employed by a typical firm in different productivity groups 22

Figure 13. Elasticities of productivity differentiated by time period and size of firm 26 


\section{Main findings}

Few would argue that they would rather "work harder" than "work smarter". Yet, the indicator that measures smart working - productivity - shows at best sluggish growth since the financial crisis. Belgium for instance has experienced little productivity growth in recent years and has only increased its labour productivity by $\sim 5 \%$ over the decade since the financial crisis. This seems to be at odds with the ever-increasing use of digital technologies that (at least in the perception of most people) increasingly replace and support human tasks. This paper, part of the OECD's "Human Side of Productivity" project, opens the firm's black box and goes beyond the often used (financial) firm-level characteristics to study a firm's human capital and its link with productivity.

Human capital will become even more relevant post-COVID19. The NextGenerationEU recovery package rightly puts significant emphasis on research, innovation, and digitalisation. The need for skilled people to deliver on these promises, however, gets little attention. Stimulating the demand for innovation without addressing the supply of skilled workers might simply result in higher wages for the high-skilled rather than additional innovation. Whilst the number of tertiary education graduates in Belgium has risen steadily over the past decades and is above the EU28 average, the number of such graduates in science, technology, engineering, and mathematics (STEM) fields is below the EU28 average. At the same time, Belgian firms have a greater need for ICT specialists, for instance. The combination of these factors has led to a steep increase in the number of firms with hard-to-fill vacancies for such jobs. When firms cannot find the human capital that they need, this is likely to have an impact on productivity.

We study the link between the skills of a firm's workforce and its productivity. To this end, we make use of linked employer-employee data and focus on the full Belgian universe of firms with 10 employees or more. We study approx. 1.5 million workers and 20,000 firms over the period 2000-2018. The skill level of an employee is based on educational attainment and categorised as high (tertiary education), medium (upper secondary education and post-secondary non-tertiary education) and low (lower secondary education or below). Firms are divided into productivity groups based on their position within the productivity distribution of their industry. We focus on the top performers or "frontier firms" (top 10\%), medium performers $(40 \%-60 \%)$ and low performers or "laggards" (bottom 10\%). Productivity is measured via labour productivity (euro per hour worked).

A frontier firm is more than twice as productive as a medium performer and almost 5 times as productive as a laggard firm. Since 2000 , this productivity gap has increased simultaneously with a skills gap. On average, the share of high-skilled workers as a percentage of total workers in a frontier firm is currently close to 10 percentage points higher than in a medium performer and 20 percentage points higher than in a laggard firm. The larger share of high-skilled workers in frontier firms is mainly compensated by a smaller share of low-skilled workers. Close to $10 \%$ of the Belgian population aged 18-25 years do not hold a secondary education certificate and are not in further training or education. We find that job opportunities for the lowest-skilled workers are mainly found in the least productive firms.

To control for a wide range of firm characteristics we use regression analysis. We find that a 10 percentage point increase in a firm's share of high-skilled workers is correlated with an increase in productivity of $2 \%$ (for knowledge-intensive services), $6 \%$ (for manufacturing) and $7 \%$ (for less knowledge-intensive services). This impact on productivity has decreased over time. For all sectors combined, a 10 percentage point increase in the share of high-skilled workers was linked with an increase in productivity of $6.5 \%$ for the period $2000-2007$ and $5.5 \%$ for the period $2012-2018$. The reason could be that the overall number of high-skilled workers is increasing and the additional benefits of continuing to add high-skilled workers decrease the more high-skilled workers a firm already employs. 
To deliver on the increased need for automation and digitalisation, there is also a need for workers with STEM skills. Although Belgium performs relatively well with respect to tertiary education graduates, its performance is poorer with respect to STEM graduates. For the manufacturing industry and the less knowledge-intensive services we do observe a clear, positive link between productivity and the share of STEM workers. For knowledge-intensive services, only the laggard firms employ a smaller proportion of STEM workers, and we see little difference between frontier firms and medium performers.

For STEM workers (high-, medium- and low-skilled) we find that a 10 percentage point increase in their share in a firm's workforce is linked with a $2.5 \%$ (for manufacturing) or $4 \%$ (less knowledge-intensive services) increase in the firm's productivity. But more importantly, unlike the impact of high-skilled workers that decreases over time, the impact of STEM workers on productivity is increasing. The average impact on productivity across all sectors combined of a 10 percentage point increase in the share of STEM workers has risen from 2.0\% (2000-2007) to 2.6\% (2012-2018). This could be linked with the increasing importance of digital technology for productivity.

Increasing the share of high-skilled STEM workers leads to significantly higher productivity gains, not only compared to non high-skilled STEM workers, but also compared to high-skilled non-STEM workers. For a typical manufacturing firm, the gains from increasing the share of high-skilled STEM workers by 10 percentage points is linked with an increase in productivity of $20 \%$ or approx. 3 to 4 times more than the gains from a 10 percentage point increase in the share of high-skilled non-STEM workers. The growing difficulty that Belgian firms experience in recruiting specialist ICT skills is therefore likely to have a significant negative impact on productivity.

Considering the results presented in this paper and bearing in mind that they mostly reflect past correlations, we can still draw some policy recommendations from this empirical exercise. The main one is that policies designed to promote the adoption of the latest technologies and business practices within firms can only lead to sustainable productivity gains if they are combined with measures to increase the supply and mobility of human (STEM) capital. Without a proper supply of skills, firms will not be able to reap the full benefits of the digital revolution.

We also briefly touch on the link between the share of foreign workers and productivity. It is only for knowledge-intensive services that the share of foreigners is positively correlated with productivity. The most productive service firms generally rely on highly skilled foreigners with specific competencies. As it remains uncertain if and when the global mobility of high-skilled workers will recover in the wake of the COVID-19 pandemic, this could have long-lasting (negative) effects on the productivity of some knowledge-intensive service firms. 


\title{
The return on human (STEM) capital in Belgium
}

\author{
By Gert Bijnens and Emmanuel Dhyne ${ }^{1}$
}

\section{Introduction}

1. Few would argue that they would rather "work harder" than "work smarter". Yet the indicator that measures smart working - productivity - shows at best sluggish growth since the financial crisis (OECD 2019). Belgium, for instance, has experienced little labour productivity growth in recent years and has only increased its labour productivity by $\sim 5 \%$ over the decade since the financial crisis (Figure 1). This seems to be at odds with the ever-increasing use of digital technologies that (at least in the perception of most people) increasingly replace and support human tasks. The (in)famous 1987 quote from Nobel prize laureate Robert Solow "you can see the computer age everywhere but in the productivity statistics" is therefore still very relevant.

\footnotetext{
${ }^{1}$ Corresponding authors are: Gert Bijnens (gert.bijnens@nbb.be) and Emmanuel Dhyne (emmanuel.dhyne@nbb.be) from the National Bank of Belgium (NBB) Economics and Research Department. The authors would like to thank Chris Brijs from Belgium's Crossroads Bank for Social Security (CBSS) for providing ready access to its data and Peter Gal and Timo Leidecker from the OECD for their fruitful cooperation. The opinions expressed here are the authors' own and do not necessarily reflect those of the institutions they are affiliated or cooperated with.
} 
Figure 1. Trend in labour productivity

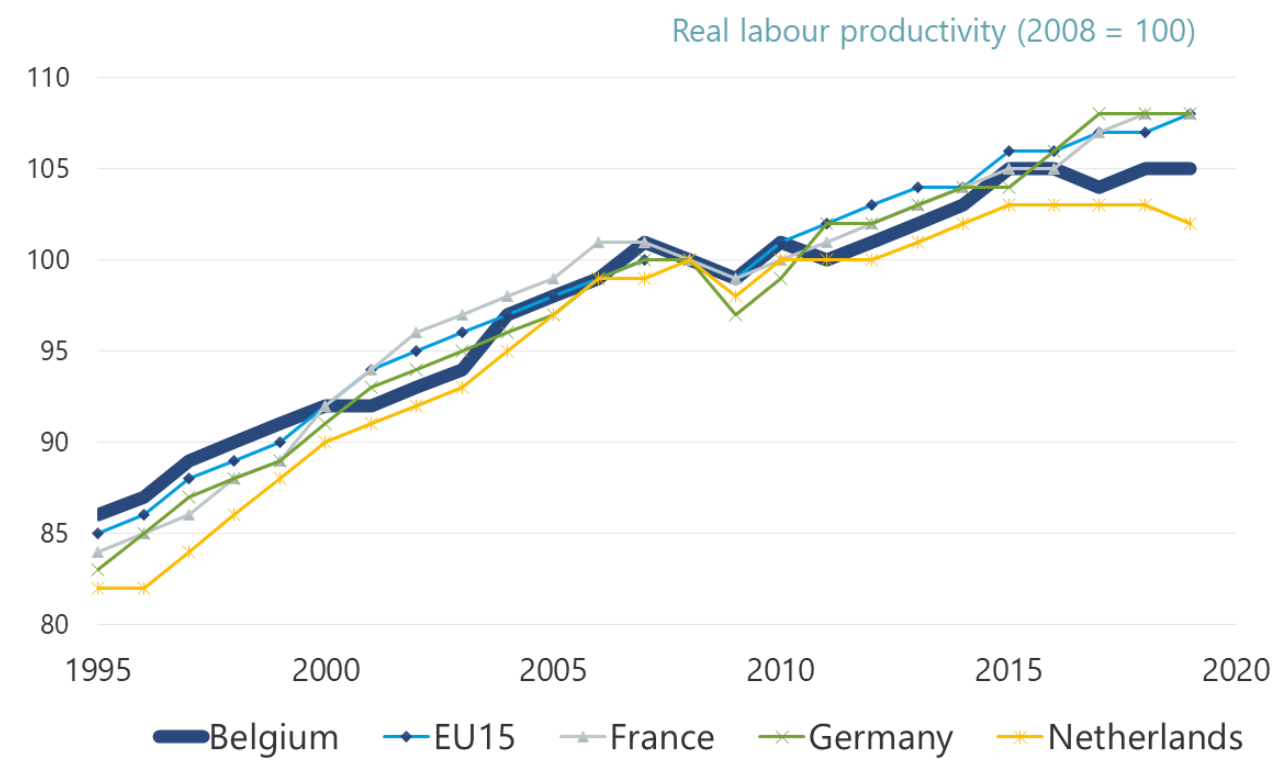

Note: Relative growth of real labour productivity per person, $2008=100$.

Source: Eurostat.

2. Numerous studies have taken a granular, firm-level perspective to solve (a part) of this productivity puzzle. A stylised fact that frequently emerges is that productivity growth is still there, but it is not a given for all firms. The top "frontier firms" increase their lead over "laggard firms" and take a bigger piece of the cake. ${ }^{2}$ The best performing firms are able to benefit from the latest technologies and newest business practices while other firms are not.

3. A possible explanation lies in the use of intangible inputs (De Ridder 2020). Brynjolfsson et al. (2021) explain the (initially) limited impact of new technologies on aggregate productivity by the need for complementary investments that support tangible investments in technology. These complementary investments refer to co-investments in new processes, products, business models and human capital which are generally intangible and poorly measured. Taking their views one step further, one could argue that a firm that lacks (a part of) the necessary human capital to complement productivity-enhancing investments will simply not be able to benefit from new technologies, even if it has sufficient funds to invest in the necessary tangible assets. This mechanism is even more relevant for countries with low job mobility and a rigid labour market (such as Belgium ${ }^{3}$ ). With low job mobility, a low productivity firm can afford to pay lower wages without seeing its workforce leave the firm (Criscuolo et al. 2021). Since it pays lower wages, such a firm will not be able to attract the (scarce) human capital needed to benefit from productivityboosting investment.

\footnotetext{
2 E.g. Andrews et al. (2019) show a growing divergence between firms that operate at the frontier, "the best", and "the rest". De Loecker et al. (2020) study U.S. publicly listed firms and the rise of firm market power. Akcigit and Ates (2019) find that there is less and less knowledge transfer between the most innovative firms and other firms. Autor et al. (2020) discusses the phenomenon of "superstar firms" where a small number of firms in an industry become highly successful.
}

3 See e.g. Calvino et al. (2020) who show that Belgium has comparably low entry, exit and job reallocation rates. Zimmer (2012) shows Belgium has the highest mismatch between labour supply and labour demand in the EU-15. 
4. The supply of human capital will become even more relevant after the COVID19 pandemic. The NextGenerationEU recovery package rightly puts significant emphasis on research, innovation, and digitalisation. The need for educated people to deliver on these promises, however, often gets little attention. Romer (2000) already pointed to the fact that stimulating the demand for innovation without addressing the supply of educated workers will simply result in higher wages for the high-skilled rather than additional innovation.

5. With the OECD's "Human Side of Productivity" project ${ }^{4}$, we open the firm's black box and go beyond the often used (financial) firm-level characteristics to study a firm's human capital. We look at the people making up the firm. In this paper focusing on Belgium, we primarily study the link between the skills of a firm's employees and its productivity. Throughout this paper we use educational attainment (with a particular interest in STEM education) as a measure for skills. ${ }^{5}$

6. The debate on whether more education truly raises productivity or just reflects it has been ongoing for decades. ${ }^{6}$ For the U.S., Fernald and Jones (2014) concluded that approximately $3 / 4$ of growth since 1950 reflects rising educational attainment and research intensity. On the basis of Belgian data covering the period 1999-2006, Kampelmann and Rycx (2012) conclude that demanding a higher level of education does not only have a positive impact on firm-level productivity, but an over-educated worker is also more productive in a job. Recently, Saks (2021) estimated for Belgium that higher educated workers earn approx. $27 \%$ more per hour than the low educated. Using also Belgian data, Lebedinski and Vandenberghe (2014) find evidence that this relationship between education and individual wages is driven by a strong positive link between education and firm-level productivity. Whilst education clearly signals worker characteristics that are not related to education as such, prior research does suggest that there is a positive impact on firm-level productivity that justifies the firm to pay a higher educated worker a higher wage.

7. STEM - and more specifically ICT education - can have an impact on productivity via several channels. Firms need skilled personnel to install and operate their ICT investments. Using Belgian data, Dhyne et al. (2020) found such investments generate substantial productivity returns, but many firms still seem to be underinvested in ICT. Gal et al. (2019) found that digital technologies might well have contributed to the growing dispersion in productivity performance across firms, and that laggard firms need more access to (digital) skills. Specifically, Bijnens and Konings (2020) show that business dynamism and entrepreneurship in Belgium was declining, and that a key factor could be that firms are becoming increasingly ICT-intensive. Some firms might not be able to attract sufficient ICT personnel, and that is increasing the digital divide.

8. The number of tertiary education graduates has risen steadily over the past two decades (Figure $2 \mathrm{~A}$ ), both in Belgium (with an increase of $75 \%$ ) and in neighbouring countries (with an increase of $50 \%$ to $100 \%$ ). Figure $2 \mathrm{~B}$ shows, however, that whilst Belgium has a relatively high number of tertiary education graduates, it has a rather low number of such graduates in STEM fields. In Belgium the number of STEM graduates amounts to $\sim 13$ per thousand of the population aged 20 years to 29 years. For Germany this is 20 and for the EU28 it is close to 20. At first sight, this seems at odds with the fact that Belgium's firms clearly have a high need for ICT specialist skills (Figure $3 \mathrm{~A}$ ). The result is that more and more firms (currently close to 70\%) are experiencing difficulties in finding ICT-skilled personnel (Figure 3B). This is

\footnotetext{
4 This study is part of broader OECD project on "Human Side of Productivity" that spans multiple countries in addition to Belgium. A detailed cross-country analysis can be found in Criscuolo, Gal, Leidecker and Nicoletti (2021).

${ }^{5}$ We are aware that educational attainment is not the only factor contributing to a worker's skill level. Additional indicators, however, were not available in the data.

6 The Human Capital Theory, i.e. the theory that suggests education and knowledge increases a person's productivity, was formalised in the 1960s (e.g., Schultz 1961). An overview of the criticism can be found in Tan (2014) who nevertheless concludes that "the existing Human Capital Theory seems to be here to stay".
} 
not only apparent in Belgium. France and Germany, however, with a higher number of STEM graduates, experience less difficulty.

9. The increased number of tertiary education graduates goes hand in hand with the steady reduction in early leavers from education (Figure 4). For Belgium this number has decreased from $~ 14 \%$ in 2000 to $\sim 8 \%$ in 2019. Belgium's neighbouring countries show a similar trend. Less than half of these early leavers are in employment. Opportunities for the least educated remain scarce, and in the wake of the COVID-19 pandemic this will require extra attention. Moldonado and De Witte (2020) study standardised test scores in the last year of primary school in Flanders and find significant learning losses for the 2020 cohort that was affected by school closures. It remains to be seen what the impact from school closures will be on future school dropout rates.

10. In addition, we briefly touch on the topic of foreign workers and examine to what extent there is a link with productivity. That is even more relevant in the aftermath of the COVID-19 pandemic. Lens et al. (2021) have recently shown that while the number of lower-skilled foreign workers in Belgium quickly recovered after the steep drop in the early months of the pandemic, the proportion of high-skilled foreign workers did not. As it remains uncertain if and when global mobility of high-skilled workers will recover, this could have long-lasting (negative) effects on productivity, given the rather large share of foreign workers in the Belgian labour force (Figure 5).

11. Section 2 of the paper proceeds to describe the various data sources that link employees with employers. Section 3 distils some stylised facts from the data. Section 4 outlines our economic framework and discusses the regression results. Section 5 concludes.

Figure 2. (STEM) tertiary education graduates

Panel A: Tertiary education graduates (all fields)

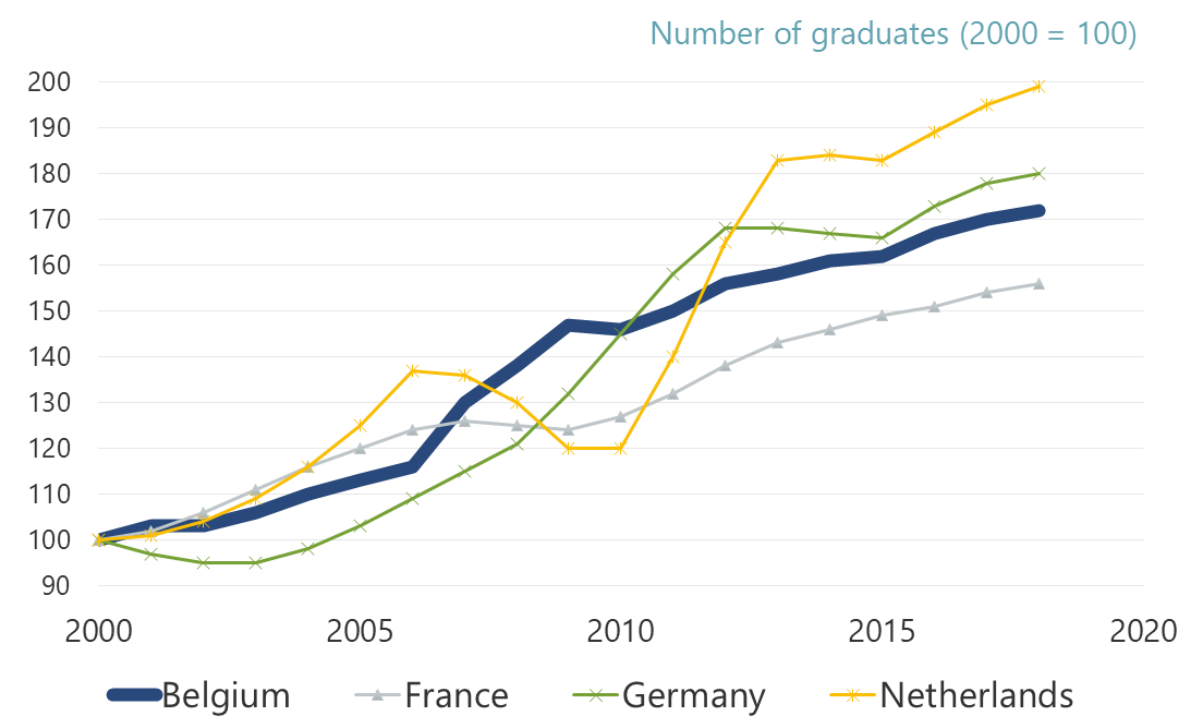


10

Panel B: Tertiary education graduates relative to population (all fields and STEM fields)

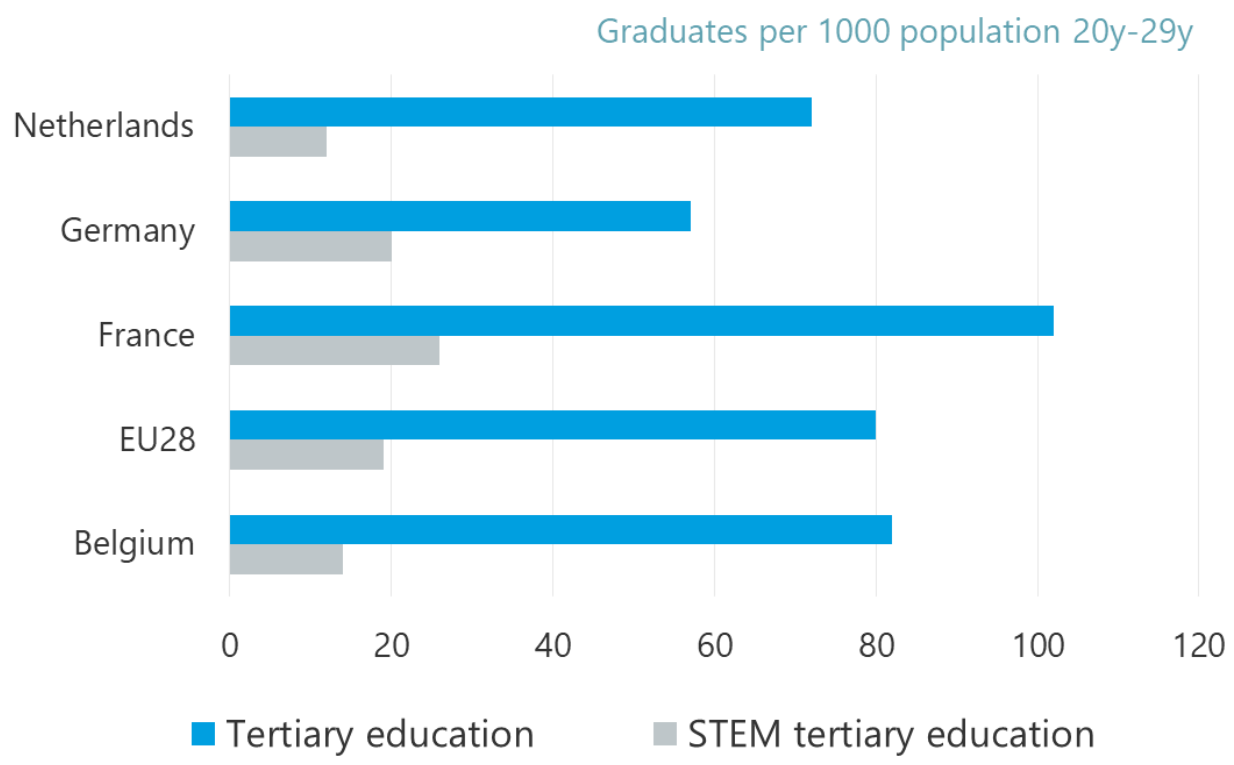

Note: Panel A shows the absolute number of graduates in tertiary education $(2000=100), 3$-year moving average as year-on-year numbers are volatile. Panel B shows figures for 2017, except EU28 ("all fields" figure for 2018 and "STEM fields" figure for 2016). STEM fields are defined as science, mathematics, computing, engineering, manufacturing, and construction.

Source: Eurostat.

Figure 3. Firms and ICT recruiting

Panel A: \% firms recruiting/trying to recruit personnel for jobs requiring ICT specialist skills, split by firm size

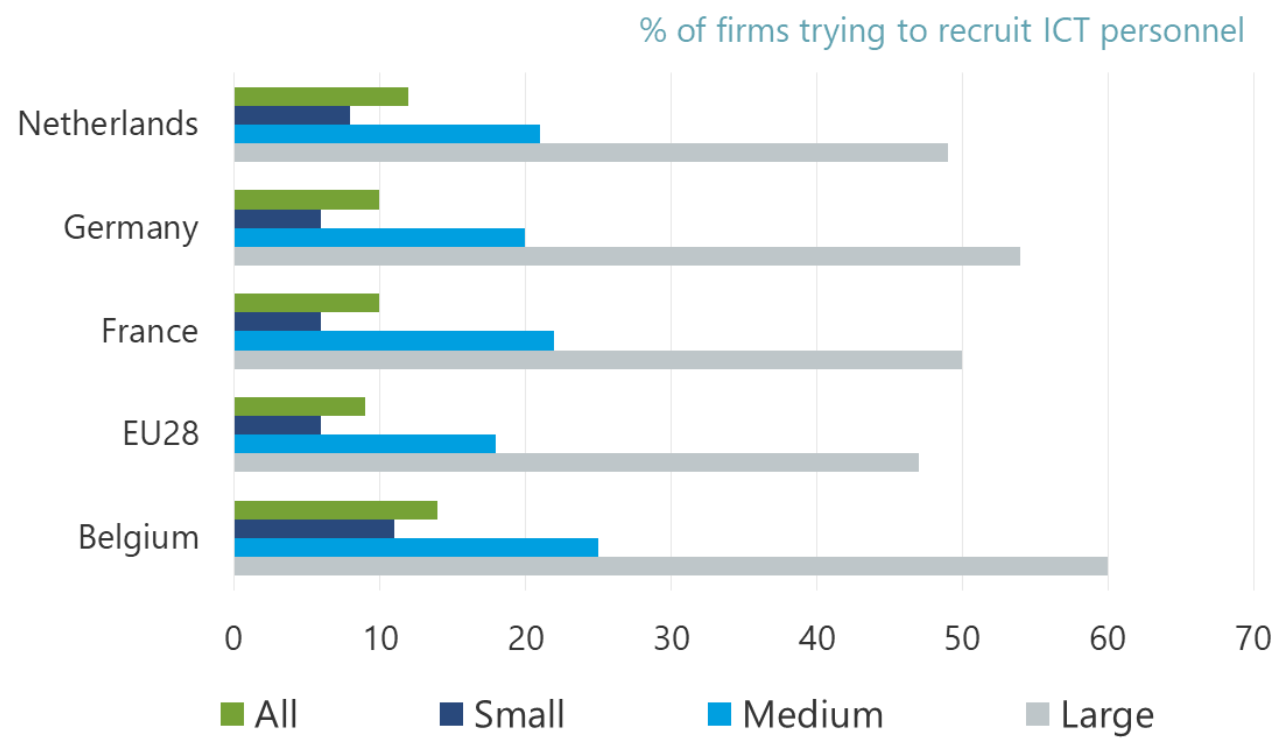


Panel B: Firms with hard-to-fill vacancies for jobs requiring ICT specialist skills as \% of enterprises which recruited / tried to recruit these skills

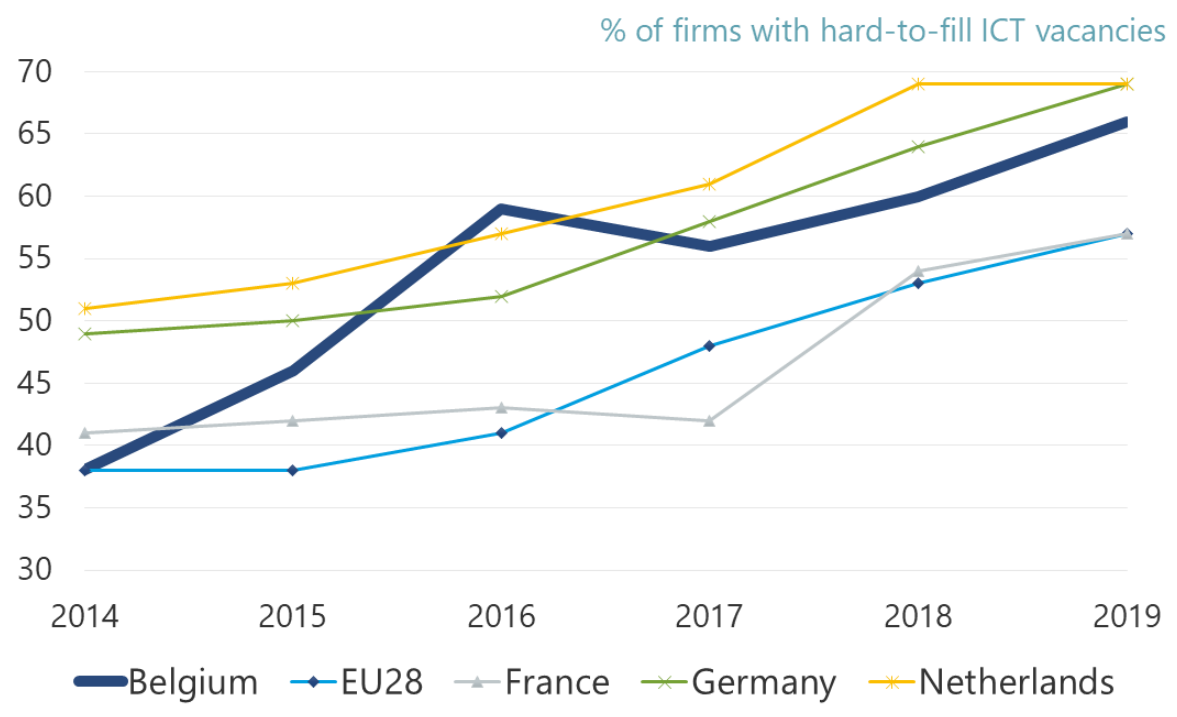

Note: Panel A figures for 2019.

Source: Eurostat.

Figure 4. The share of early leavers from education

Early leavers from education as \% of population aged $18-24$

$20 \%$

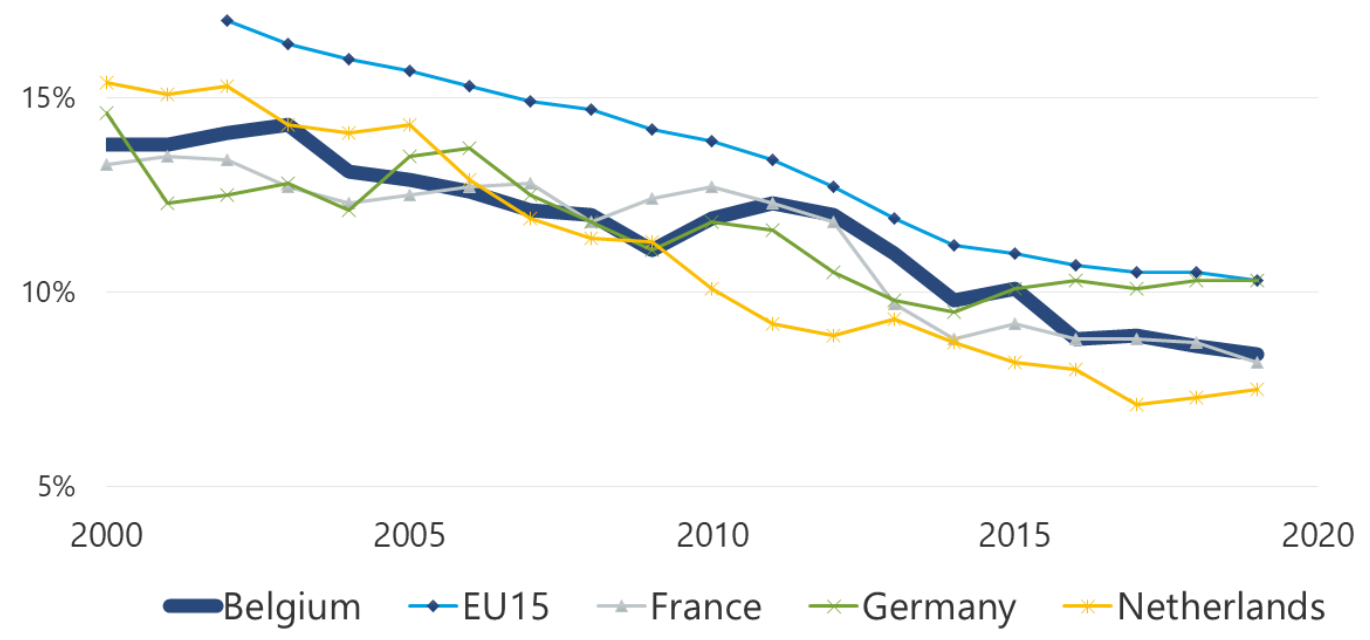

Note: Share calculated in \% of those aged 18-24 with at most lower secondary education (i.e. low-skilled according to the definition used in this paper) and who were not in further education or training.

Source: Eurostat. 
Figure 5. Share of foreigners in the workforce

Foreigners as $\%$ of the workforce

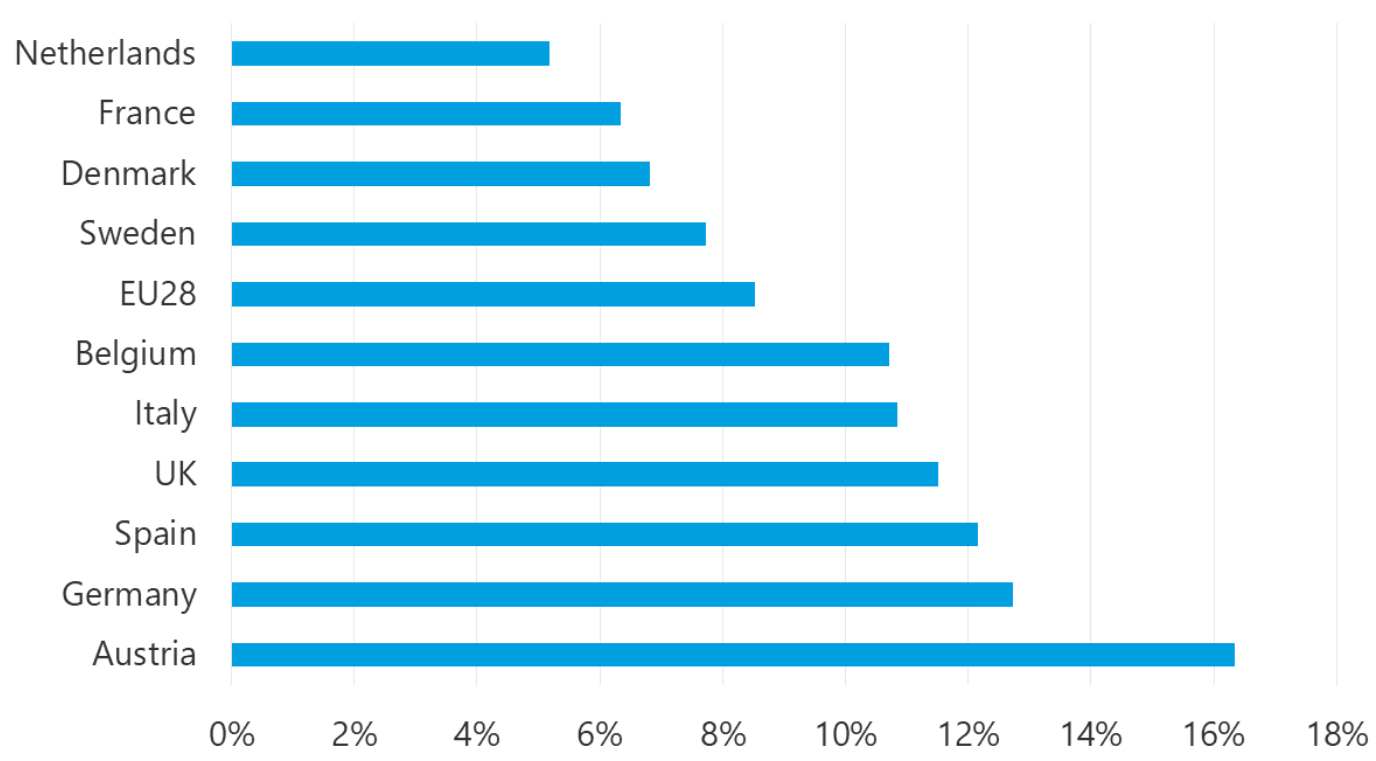

Note: Share calculated as the number of foreign nationals employed vs. the total number of people employed aged 15-64 years. Number for 2019.

Source: Eurostat.

\section{Data and definitions}

12. We make use of linked employer-employee data (LEED) where employee-level data is linked with the firm-level data of the employer.

13. The employee-level data is obtained from Belgium's Crossroads Bank for Social Security (CBSS). The data includes information on all individual employees ${ }^{7}$ working for an entity having a Belgian social security ID. We make use of an employee's wage, hours worked, nationality, plus level and field of education (ISCED 1997). The firm-level data is gathered from the National Bank of Belgium's (NBB) balance sheet office. This database contains the unconsolidated annual accounts of all for-profit enterprises incorporated under Belgian law that are legally required to file their annual accounts with the NBB. ${ }^{8}$ We use information on turnover, added value, total number of employees, total number of hours worked, firm age and industry (NACE Rev. 2 2008). We exclude the agricultural and mining sectors and firms with less than 10 employees. ${ }^{9}$ The period covered in our analysis is $2000-2018$.

14. Workers are categorised into skill-groups based on education: low-skilled (lower secondary education or below), medium-skilled (upper secondary education and post-secondary non-tertiary

\footnotetext{
${ }^{7}$ Self-employed workers are hence excluded.

8 This excludes financial institutions. For firms that do not report turnover in their annual accounts, we use their VAT returns.

${ }^{9}$ Our analysis is primarily based on the share (percentage) of certain types of workers in the total workforce. For micro firms this share is volatile driven by the addition/change of a limited number of workers and this will disproportionally impact the results.
} 
education) or high-skilled (tertiary education). Workers with STEM skills are defined as workers having a degree in sciences (ISCED 4) or engineering (ISCED 5).

15. Industries are grouped together according to the OECD STAN A38 classification and can be subdivided into manufacturing, knowledge-intensive services (KIS) and less knowledge-intensive services (LKIS). See Annex A.1 for the detailed industry classification.

16. Firm labour productivity is calculated as added value per hour worked. Outliers, defined as the top/bottom percentile of the annual productivity growth rate distribution by industry, are excluded, as are firms that do not report added value or hours worked.

17. All variables used are based on 3-year moving averages, the first available year is hence 2002 .

Table 1 summarises the data.

Table 1. Summary of main data statistics

\begin{tabular}{c|c|c|c|c}
\hline Year & $\begin{array}{c}\text { Number of } \\
\text { workers }\end{array}$ & Number of firms & $\begin{array}{c}\text { Average number of } \\
\text { workers per firm }\end{array}$ & $\begin{array}{c}\text { Median number of } \\
\text { workers per firm }\end{array}$ \\
\hline 2002 & $1,390,894$ & 17,588 & 79 & 24 \\
\hline 2003 & $1,367,312$ & 17,508 & 78 & 23 \\
\hline 2004 & $1,388,779$ & 17,747 & 78 & 23 \\
\hline 2005 & $1,425,340$ & 18,065 & 79 & 23 \\
\hline 2006 & $1,483,762$ & 18,357 & 81 & 23 \\
\hline 2007 & $1,532,013$ & 18,669 & 82 & 23 \\
\hline 2008 & $1,586,305$ & 19,006 & 83 & 23 \\
\hline 2009 & $1,563,023$ & 18,897 & 83 & 23 \\
\hline 2010 & $1,540,067$ & 18,898 & 81 & 23 \\
\hline 2011 & $1,541,449$ & 19,173 & 80 & 23 \\
\hline 2012 & $1,537,557$ & 19,256 & 80 & 22 \\
\hline 2013 & $1,502,267$ & 19,504 & 77 & 22 \\
\hline 2014 & $1,428,454$ & 19,402 & 74 & 22 \\
\hline 2015 & $1,419,939$ & 19,459 & 73 & 22 \\
\hline 2016 & $1,458,948$ & 19,634 & 74 & 74 \\
\hline 2018 & $1,462,366$ & 19,796 & 73 & 23 \\
\hline
\end{tabular}

Note: Number of workers, average and median value based on 3-year moving average. Number of firms implies the number of firms in a certain year that reported these values over the past 3 years.

Source: Authors' calculations based on linked employer-employee data.

\section{Descriptive evidence}

18. For the analysis in this section, we divide firms into 5 productivity groups based on their position within the productivity distribution of their 2-digit industry, with

- Top performers or "frontier firms": top $10 \%$

- High-medium performers: $60 \%-90 \%$

- Medium performers: $40 \%-60 \%$

- Low-medium performers: $10 \%-40 \%$ 
- Low performers or "laggards": bottom $10 \%$

19. We define a cell as the combination of productivity group $x$ industry $x$ year. Cells with less than 3 firms are excluded as are cells where a single firm represents more than $80 \%$ of the cell's total turnover. ${ }^{10}$ All variables used are based on 3-year moving averages.

20. Figure 6 shows the productivity gap for a typical firm (medium performer) and a laggard firm compared to a frontier firm, using simple averages across all 2-digit sectors and over time. We can confirm that the gap is significant, even within the same industry. Based on all firms (Figure 6A), a medium performer is $\sim 60 \%$ less productive than a frontier firm and a laggard is $\sim 80 \%$ less productive. The productivity gap is somewhat smaller for manufacturing (Figure 6B). The gap is clearly persistent over time and is increasing slightly for manufacturing, knowledge-intensive services (KIS, Figure 6C) and less knowledge-intensive services (LKIS, Figure 6D).

21. Figure 7 gives the skills composition of a frontier firm, a medium performer, and a laggard firm. From Figure 7A we learn that the more productive a firm is, the more high-skilled workers it will employ. A frontier firm typically employs 5 percentage points (pp) to $10 \mathrm{pp}$ more high-skilled employees than a medium performer, while the gap in relation to a laggard firm is about $20 \mathrm{pp}$. The difference for mediumskilled employees is less pronounced, suggesting that the dominant performance driver is the proportion of high-skilled workers. The pattern is consistent across industries, with the exception of knowledgeintensive services (Figure 7C) where we observe limited differences between a medium performer and a firm at the frontier.

22. The gap for high-skilled workers has not been constant over time. Looking at all firms (Figure 8A), we observe that the gap between frontier firms and other firms has increased, especially after the period of the financial crisis. Frontier firms have performed better at hiring and/or keeping high-skilled employees over the past decade and have increased the gap by almost $5 \mathrm{pp}$.

23. Figure $8 \mathrm{C}$ shows the change in the skills gap for knowledge-intensive services over time. Whilst on average (Figure $8 \mathrm{C}$ ) there seems to be little difference in the proportion of highly-skilled workers employed in a frontier firm compared to a medium performer, this average over the period $2002-2018$ conceals changes over time. Figure $8 \mathrm{C}$ shows that the gap was almost closed during the period of the financial crisis but has widened to nearly $10 \mathrm{pp}$ since. We observe a similar pattern for the gap between frontier and laggard firms.

24. Looking specifically at STEM skills (Figure 9A), we again observe that more productive companies employ a higher share of STEM workers. Whilst at first sight there seems to be little difference between a firm at the frontier and a medium performer, the gap narrowed at the beginning of the period studied but has widened again since the financial crisis (Figure 10A).

25. In Figure 9C we observe for knowledge-intensive services that medium performers employ a higher share of STEM workers than frontier firms. However, frontier firms employ a larger percentage of high-skilled non-STEM workers. Knowledge-intensive service firms seem to benefit more from high-skilled non-STEM workers than from STEM workers. For manufacturing and less knowledge-intensive services we do see a gap with respect to STEM workers, and this gap has increased significantly over time, especially for the less knowledge-intensive services (Figure 10D).

26. To better understand the impact of the ICT revolution we also use an alternative classification for the different industries. The knowledge-intensive vs. less knowledge-intensive classification doesn't necessarily capture the underlying dynamics of an industry. For instance, wholesale and retail activities are generally not classified as highly innovative; nevertheless, the use of ICT has dramatically increased

\footnotetext{
${ }^{10}$ Cells with less than 3 firms have volatile characteristics and disproportionately impact the graphical analysis based on simple averages. The regression analysis described in the next section, however, does not exclude the firms belonging to these cells.
} 
and has become a key success driver for this industry. To capture the impact of ICT, we use the EU KLEMS Productivity and Growth Accounts at industry level for Belgium. ${ }^{11}$ The dataset provides us with the change in contribution of ICT capital services to value added growth based on the STAN A38 industry classification. ${ }^{12}$ In sectors where the change has been substantial, companies which did not successfully invest in ICT saw a disproportionate impact on their value added growth (compared to other industries) and were hence more likely to stagnate. As the acquisition of ICT knowledge and infrastructure is, to a certain extent, a fixed cost, some companies might not have made the required investments and were not able to increase their productivity. Figure 11 now shows the productivity gap (Panel A and B) and the highskilled STEM gap (Panel C and D) between ICT-intensive and non-ICT-intensive industries. We see that the productivity gap is indeed significant, and it is particularly large for the ICT-intensive industries (Figure 11A). For non-ICT-intensive industries, the productivity gap has remained fairly stable (Figure 11B). In the case of high-skilled STEM workers in ICT-intensive industries we see that the gap is especially significant for the laggard firms (Figure 11C). For medium performers in ICT-intensive services, the gap in relation to frontier firms is smaller compared to that for medium performers in non-ICT-intensive industries (Figure 11D). These figures indicate that laggard firms in ICT-intensive services, in particular, have (very) poor access to high-skilled STEM workers. Since medium performers in ICT-intensive services do not seem to experience an increased high-skilled STEM gap (at least pre-crisis vs. post crisis), (poor) access to STEM workers cannot be the only explanation of the widening productivity gap.

27. Finally, Figure 12 shows the percentage of foreign workers in a typical firm for the different productivity groups. ${ }^{13}$ We observe that firms rely on foreigners for $4 \%$ to $8 \%$ of their workforce. It is only in knowledge-intensive services that the share of foreign workers is positively correlated with productivity. The most productive service firms generally rely on highly skilled foreigners with specific competencies. Since global mobility of high-skilled workers has been halted during the pandemic, and as it remains uncertain if and when it will fully recover, this could have long-lasting (negative) effects on the productivity of some knowledge-intensive service firms.

\footnotetext{
11 See Jäger (2017) for an explanation of the EU KLEMS project and its data sources.

12 The classification into ICT- and non-ICT-intensive industries via this methodology can be found in Annex A.1.

${ }^{13}$ Due to the limited availability of data on the educational background of foreign workers, it is not possible to classify foreign workers according to their skills.
} 
Figure 6. The productivity gap for a medium performer a laggard compared to a frontier firm

Panel A: All sectors

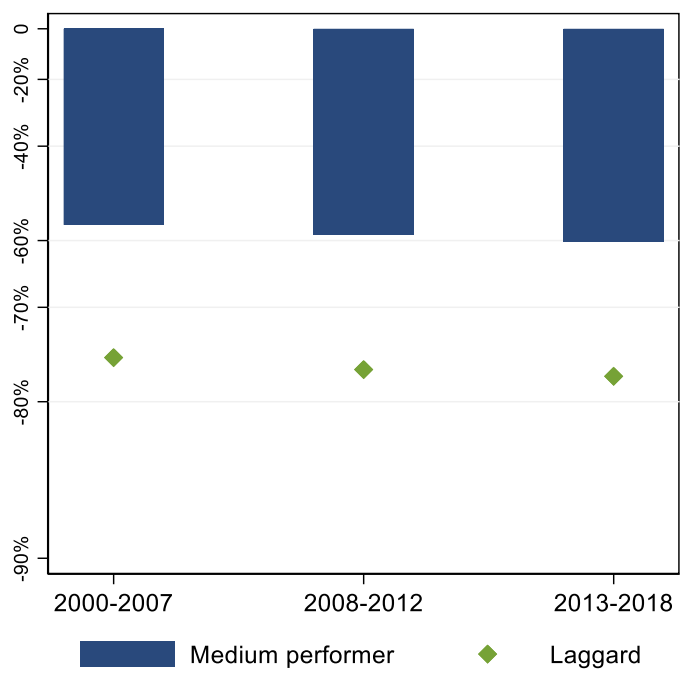

Panel C: Knowledge-intensive services

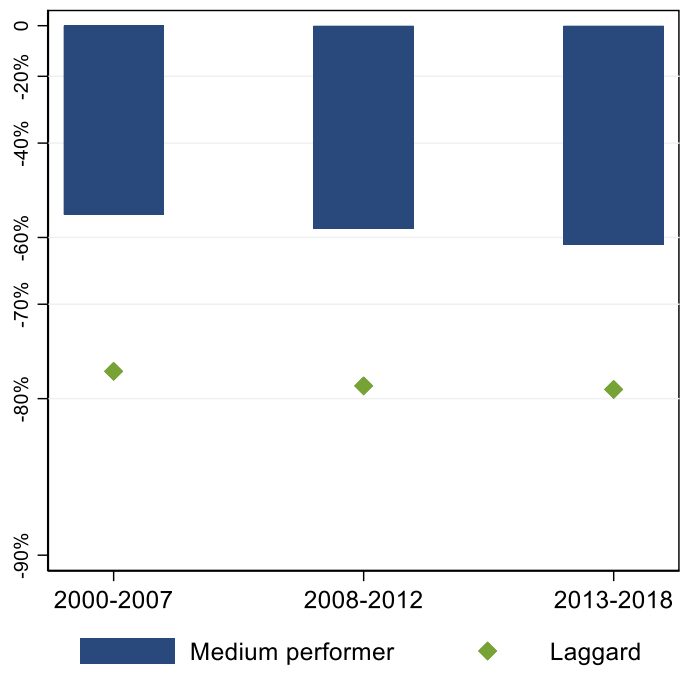

Panel B: Manufacturing

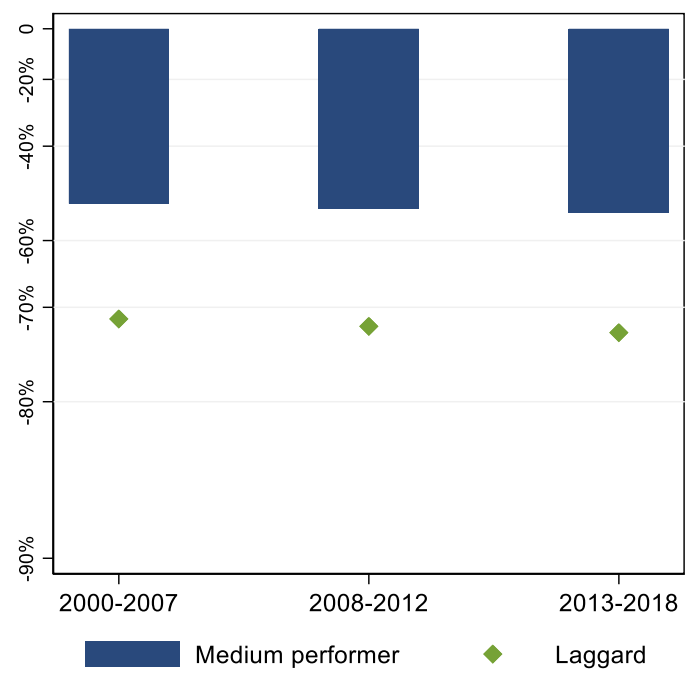

Panel D: Less knowledge-intensive services

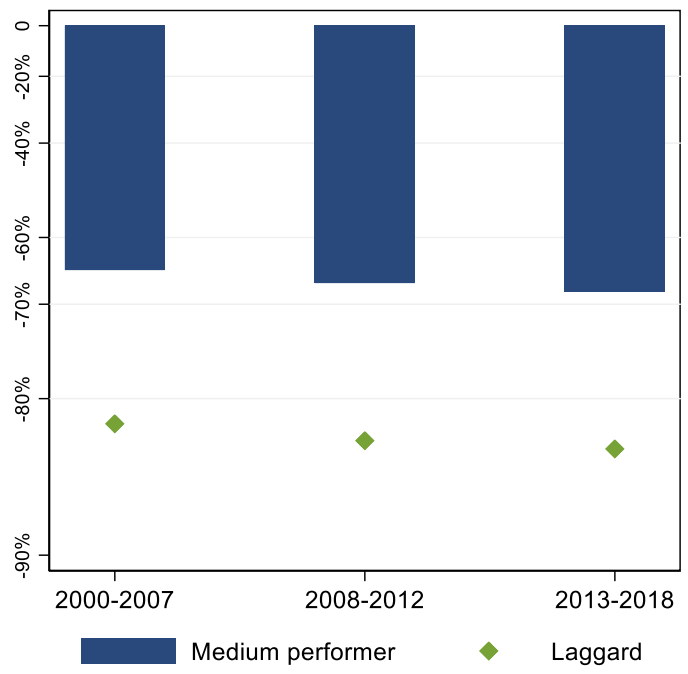

Note: The figure shows the labour productivity gap for a medium firm and a laggard firm compared to a frontier firm as a percentage of a frontier firm's productivity. Y-axis in logarithmic scale. The productivity measure is a simple average over 2-digit industries for a productivity group. Source: Authors' calculations based on linked employer-employee data. 
Figure 7. Skill profile of a typical firm for different productivity groups

Panel A: All sectors

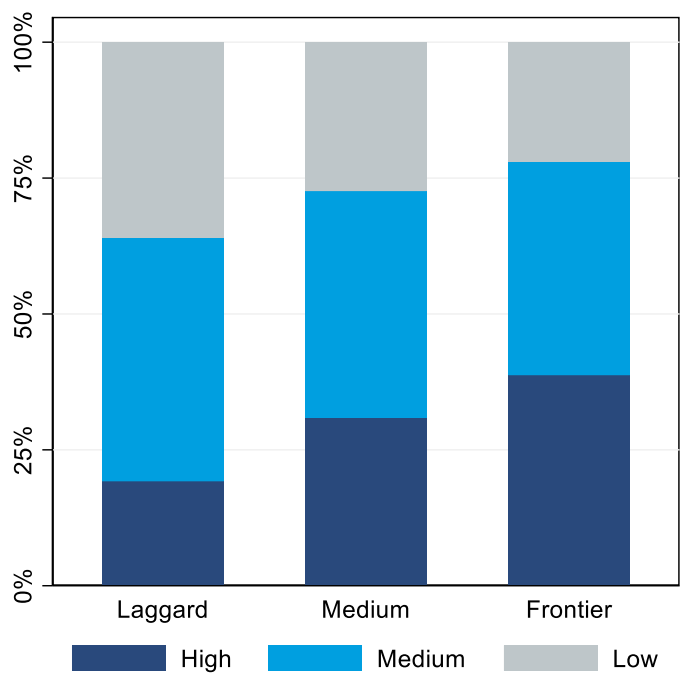

Panel C: Knowledge-intensive services

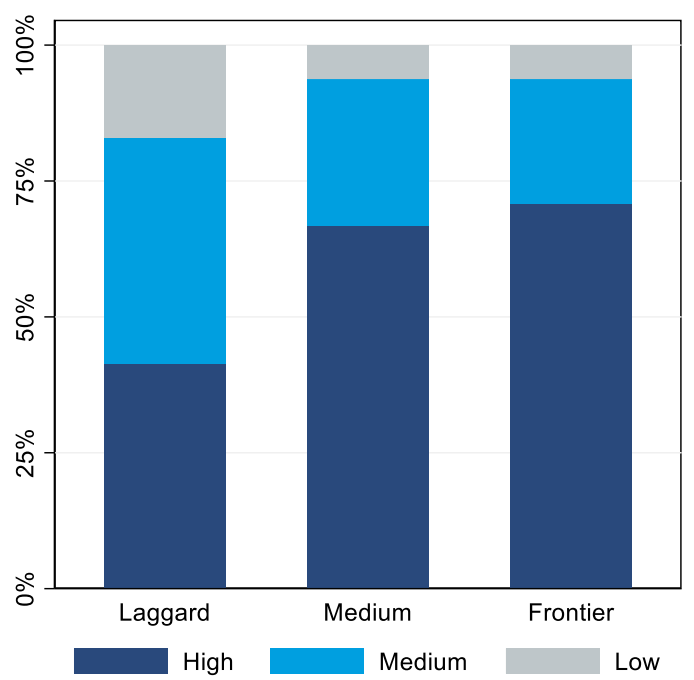

Panel B: Manufacturing

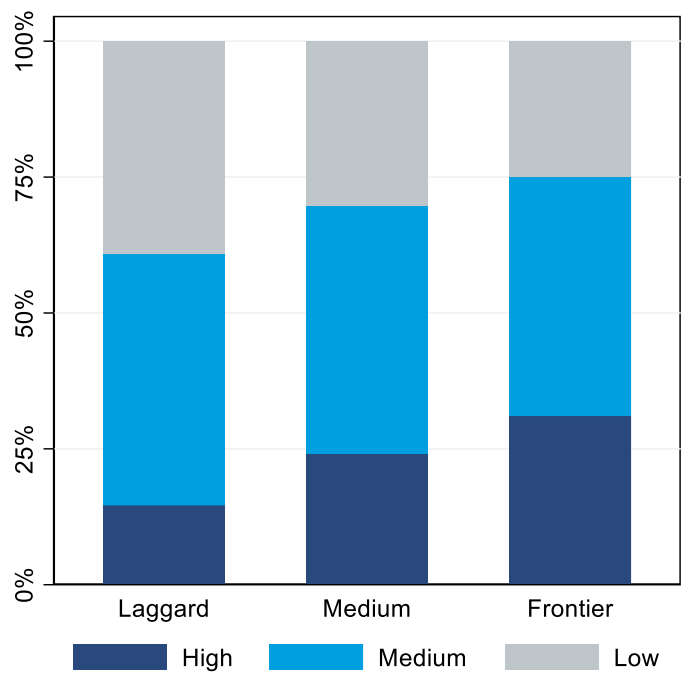

Panel D: Less knowledge-intensive services

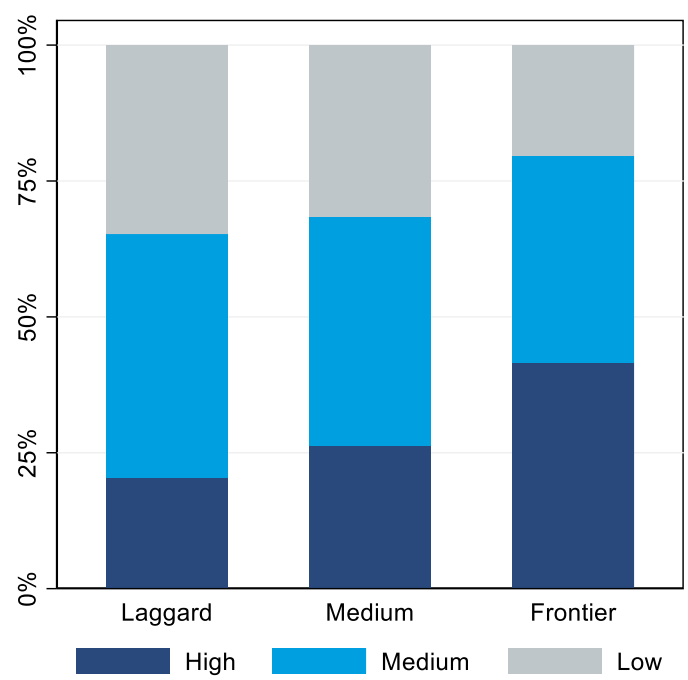

Note: Employment share of high-, medium- and low skilled-employees, for laggards, medium performers and firms at the frontier, using simple averages across all 2-digit sectors and over time. An industry x productivity group is excluded for the whole period if there are fewer than 3 firms in any 1 year.

Source: Authors' calculations based on linked employer-employee data. 
Figure 8. The gap for high-skilled workers (difference in share of high-skilled workers) in a medium performer and a laggard compared to a frontier firm

Panel A: All sectors

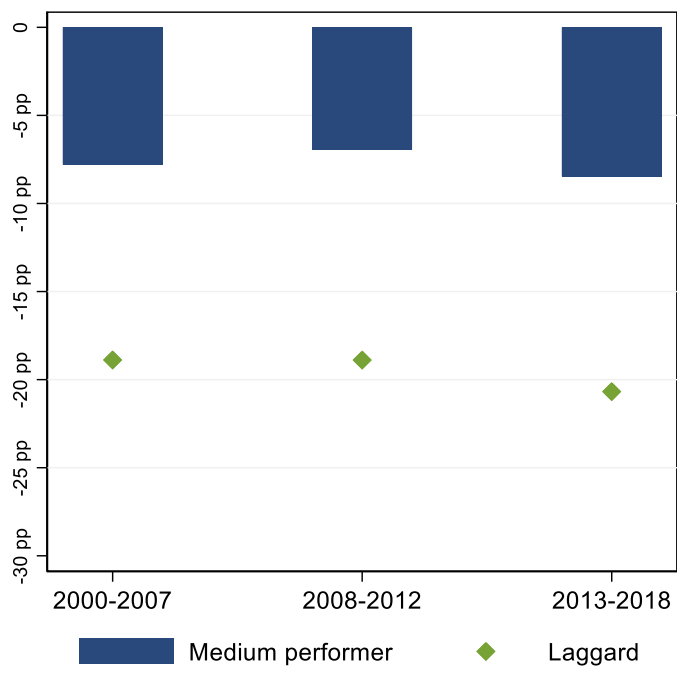

Panel C: Knowledge-intensive services

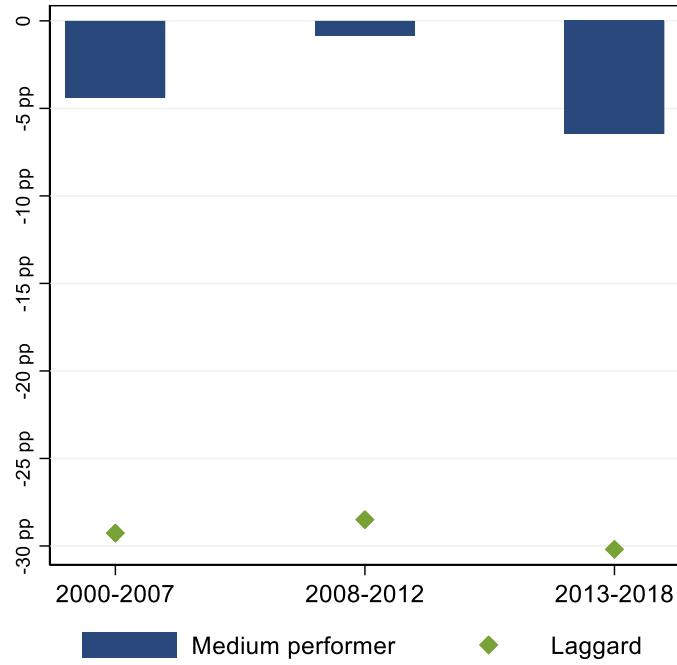

Panel B: Manufacturing

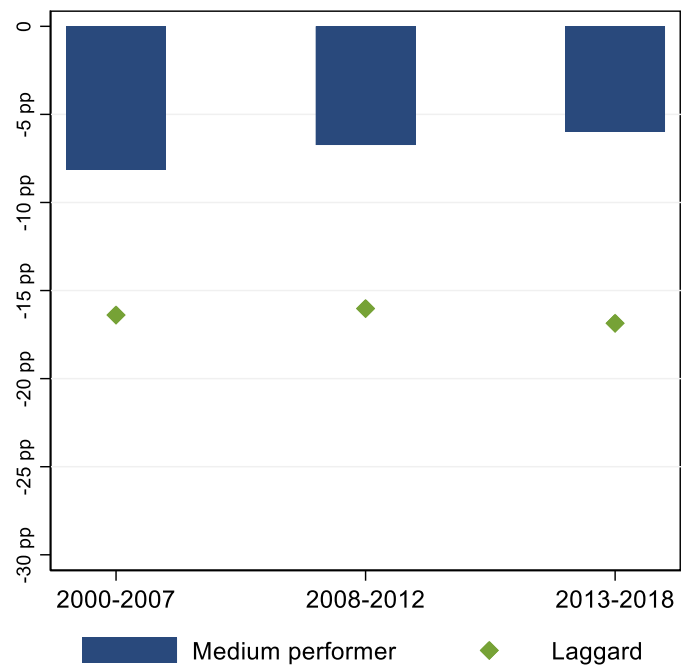

Panel D: Less knowledge-intensive services

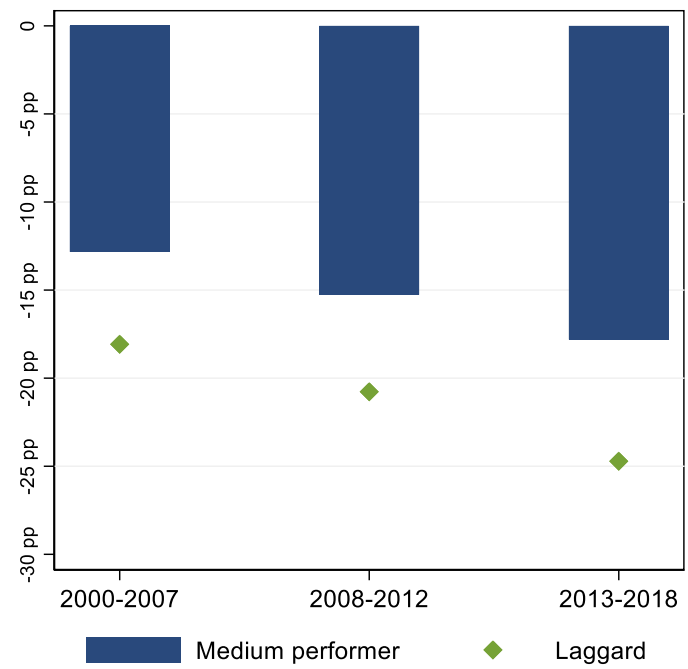

Note: The employment share for high-skilled workers is a simple average over 2-digit industries for laggards, medium performers and firms at the frontier. The gap is measured as the difference in percentage points. An industry x productivity group is excluded for the whole period if there are fewer than 3 firms in any one year.

Source: Authors' calculations based on linked employer-employee data. 
Figure 9. STEM skill profile of a typical firm in different productivity groups

Panel A: All sectors

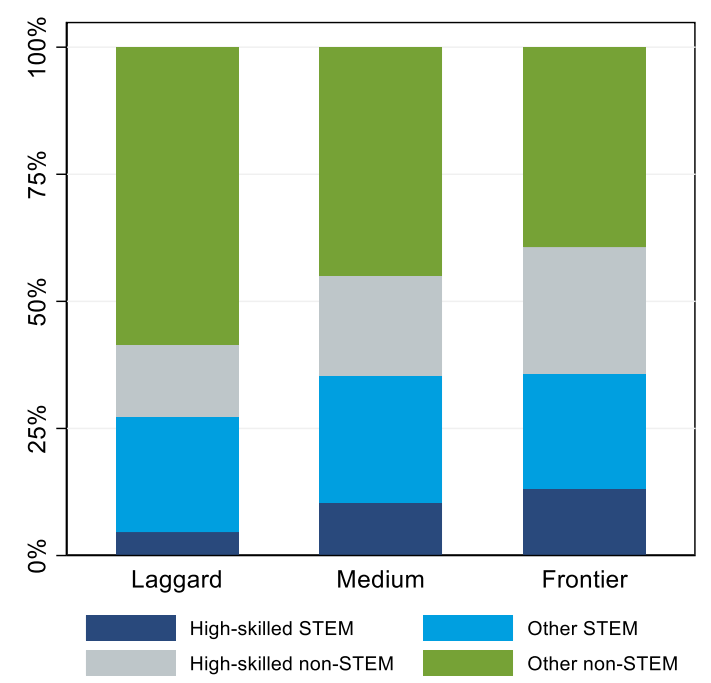

Panel C: Knowledge-intensive services

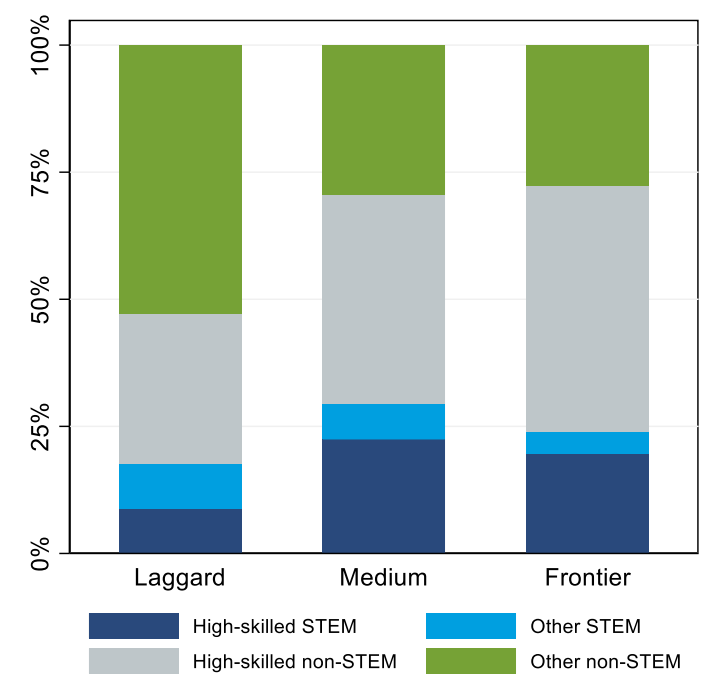

Panel B: Manufacturing

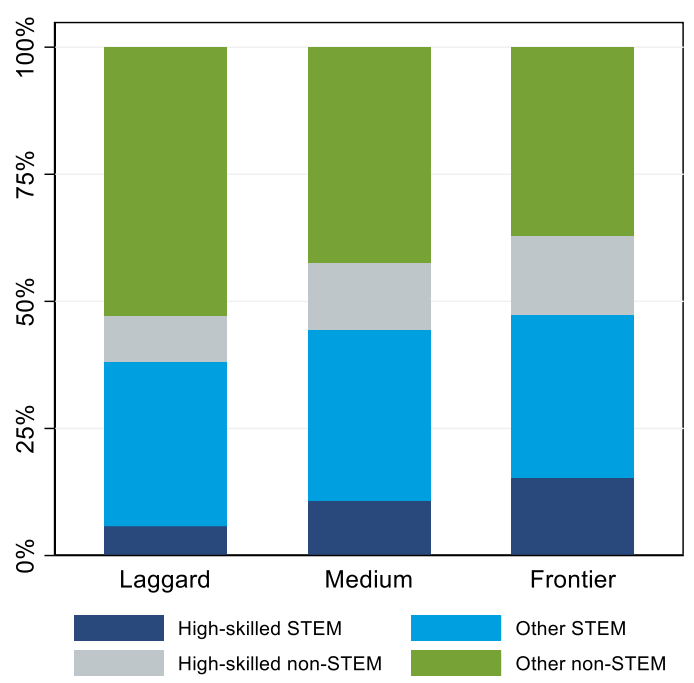

Panel D: Less knowledge-intensive services

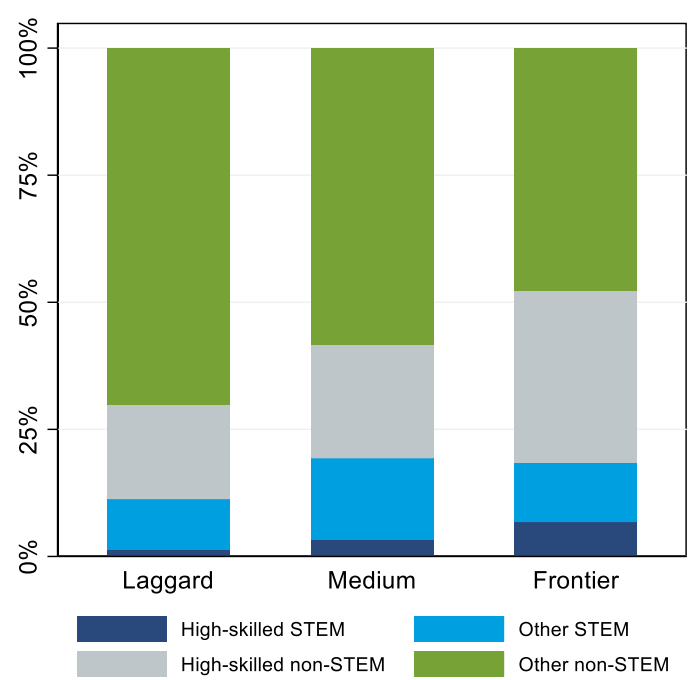

Note: The employment share for high-skilled and other (medium- and low-skilled) workers both for STEM skills and for non-STEM skills is a simple average over 2-digit industries for laggards, medium performers and firms at the frontier. An industry x productivity group is excluded for the whole period if there are fewer than 3 firms in any one year.

Source: Authors' calculations based on linked employer-employee data. 
Figure 10. The gap for high-skilled STEM workers (difference in share of high-skilled STEM workers) of a medium performer and a laggard compared to a frontier firm

Panel A: All sectors

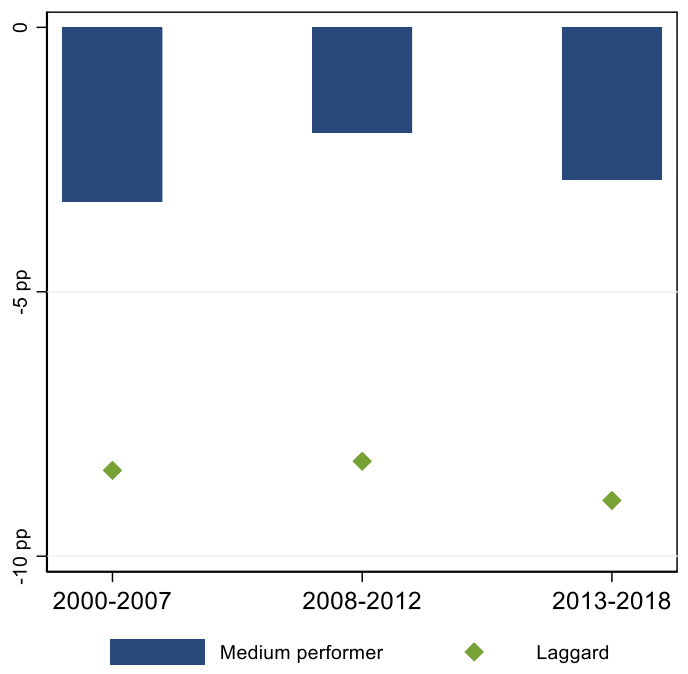

Panel C: Knowledge-intensive services

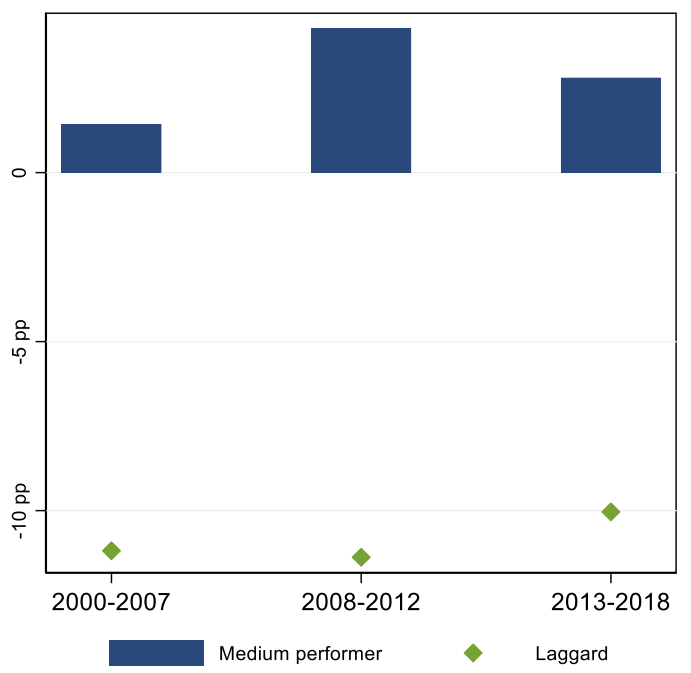

Panel B: Manufacturing

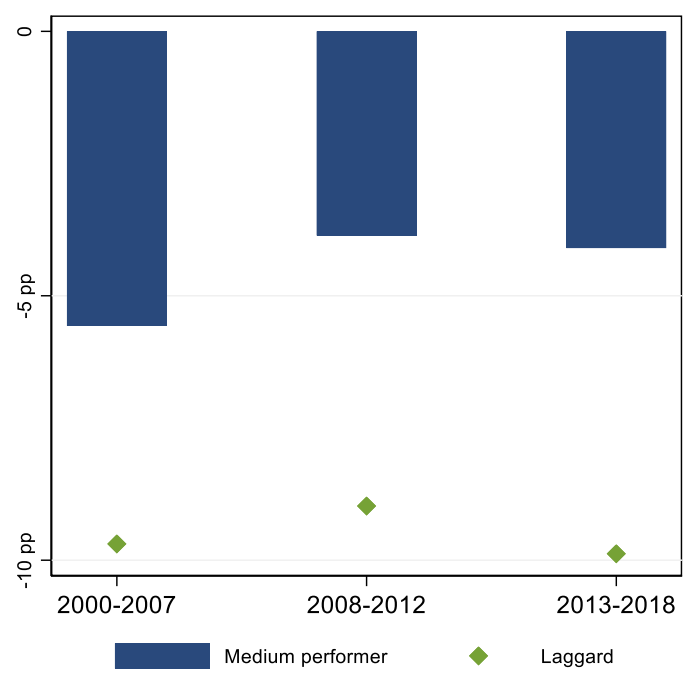

Panel D: Less knowledge-intensive services

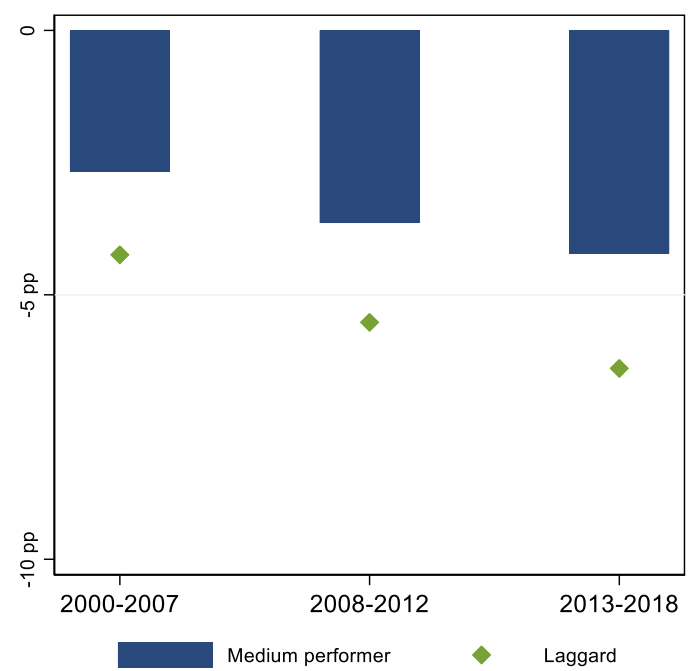

Note: The employment share for high-skilled STEM workers is a simple average over 2-digit industries for laggards, medium performers and firms at the frontier. The gap is measured as the difference in percentage points. An industry $x$ productivity group is excluded for the whole period if there are fewer than 3 firms in any one year.

Source: Authors' calculations based on linked employer-employee data. 
Figure 11. The productivity gap and high-skilled STEM gap of a medium performer and a laggard compared to a frontier firm for ICT-intensive and non-ICT-intensive sectors

Panel A: Productivity gap ICT-intensive

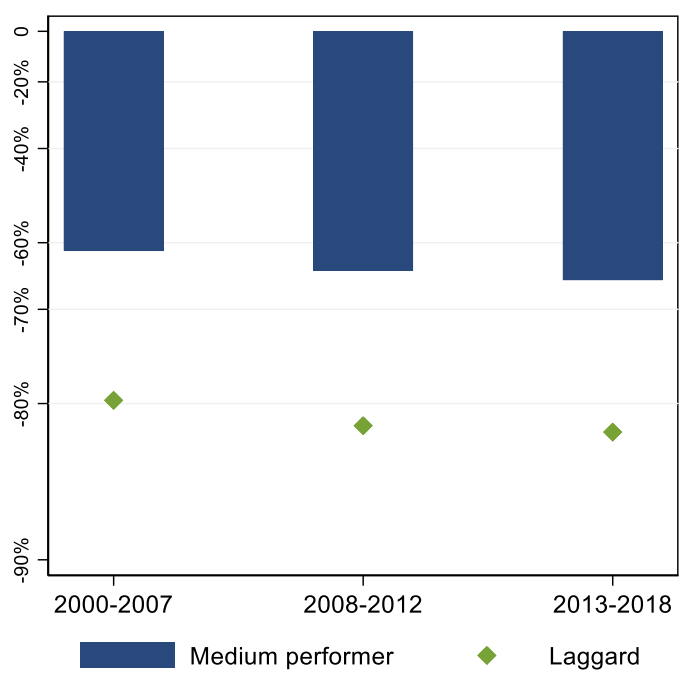

Panel C: High-skilled STEM gap ICT-intensive

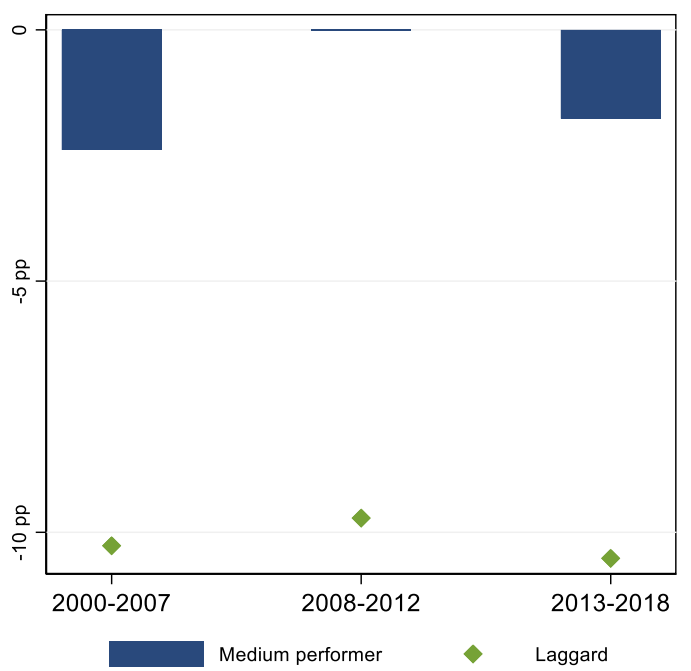

Panel B: Productivity gap non-ICT-intensive

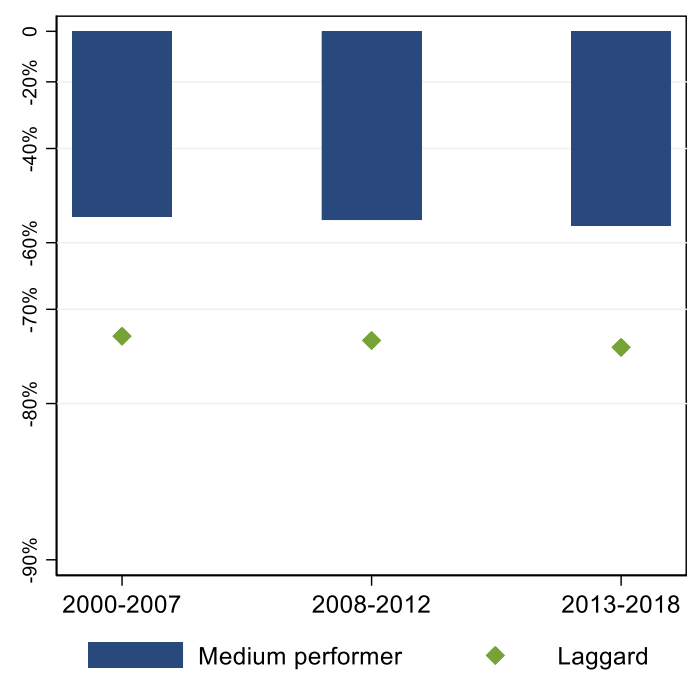

Panel D: High-skilled STEM gap non-ICT-intensive

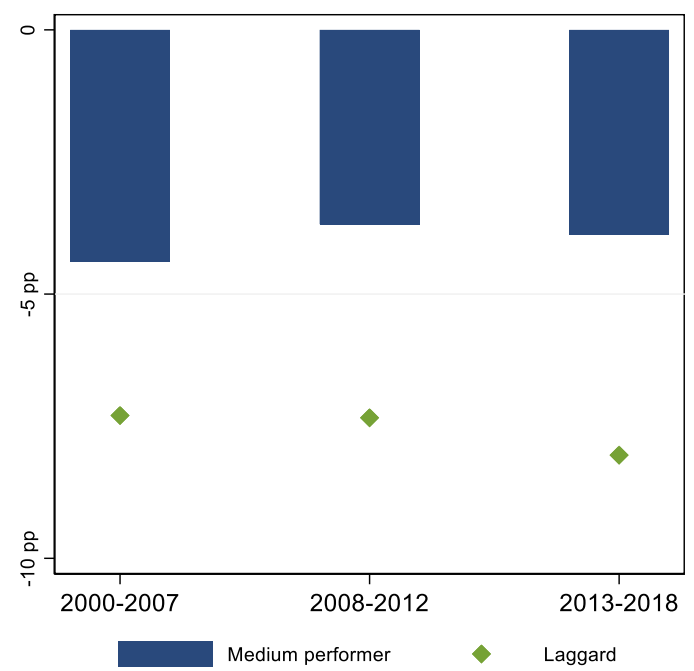

Note: List of ICT- vs. non-ICT-intensive industries as defined in Annex A.1. The figure shows the labour productivity difference for a mediumfirm and a laggard firm compared to. a frontier firm as a percentage of a frontier firm's productivity. Y-axis in logarithmic scale. The productivity measure is a simple average over 2-digit industries for a productivity group. The employment share for high-skilled STEM workers is a simple average over 2-digit industries for laggards, medium performers and firms at the frontier. The gap is measured as the difference in percentage points. An industry x productivity group is excluded for the whole period if there are fewer than 3 firms in any one year.

Source: Authors' calculations based on linked employer-employee data. 
Figure 12. Foreigners employed by a typical firm in different productivity groups

Panel A: All sectors

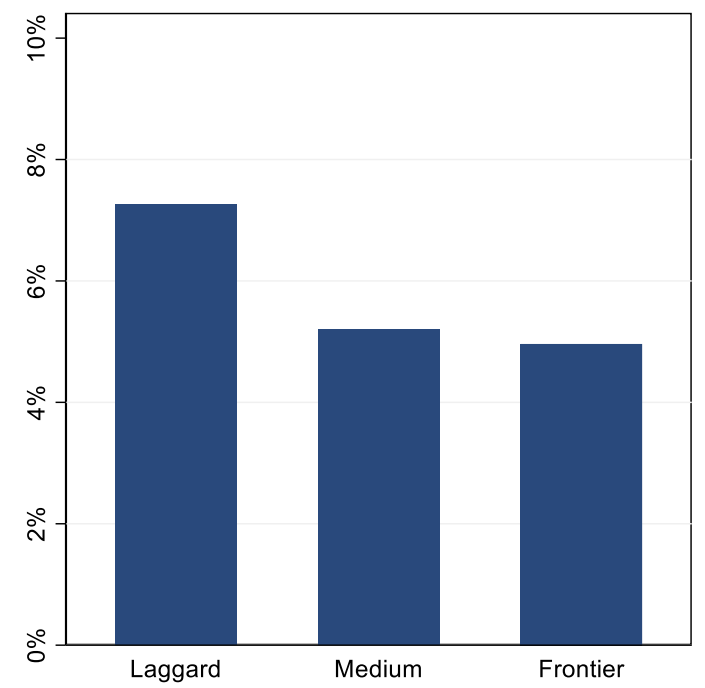

Panel C: Knowledge-intensive services

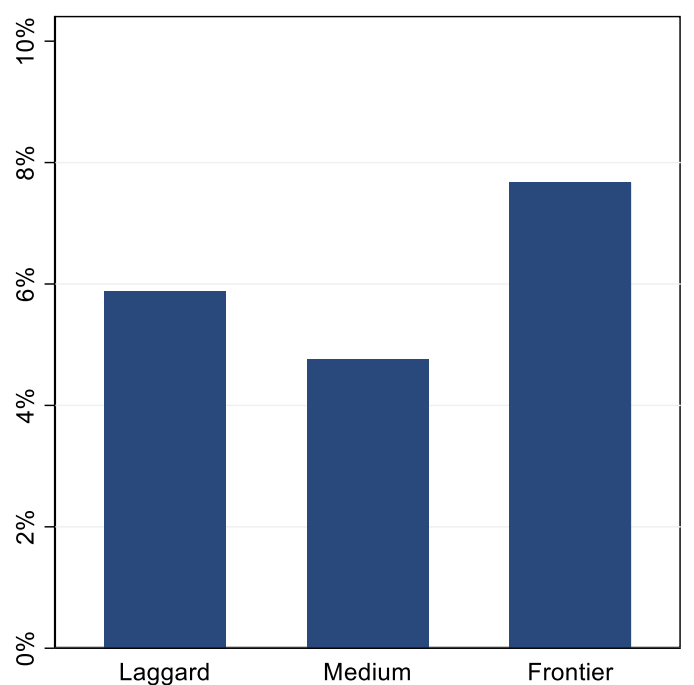

Panel B: Manufacturing

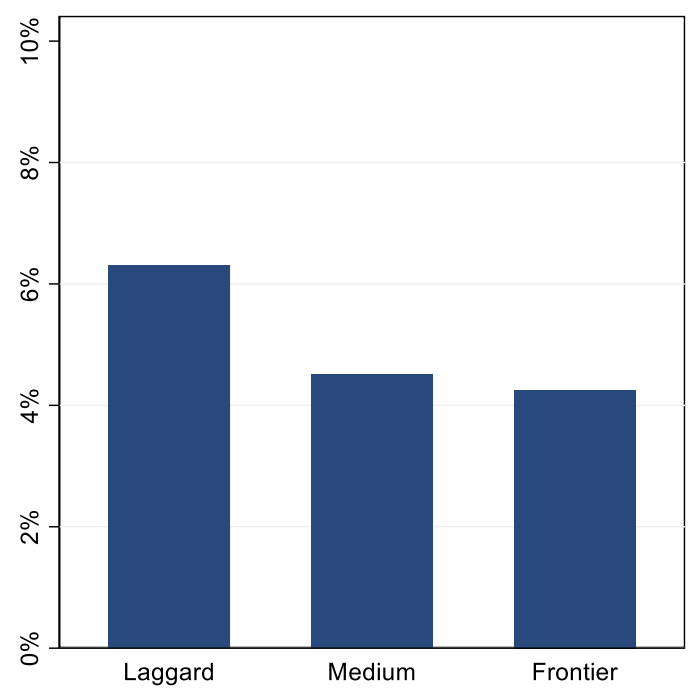

Panel D: Less knowledge-intensive services

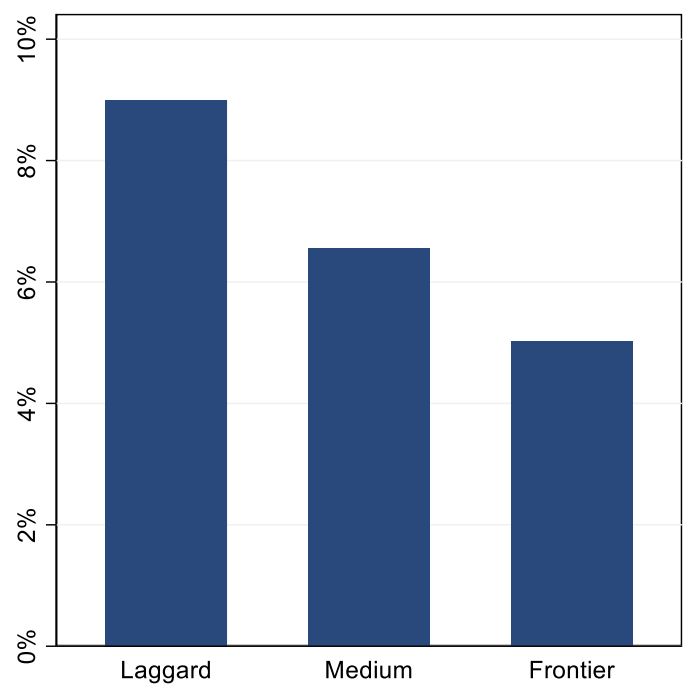

Note: The employment share for foreign workers is a simple average over 2-digit industries for laggards, medium performers and firms at the frontier. The gap is measured as the difference in percentage points. An industry x productivity group is excluded for the whole period if there are fewer than 3 firms in any one year.

Source: Authors' calculations based on linked employer-employee data.

\section{Empirical findings}

28. To better quantify the firm-level "return on human capital" we use regression analysis and specify the following model:

$$
\operatorname{prod}_{i t}=\alpha H C_{i t}+\beta X_{i t}+F E_{s t}+\epsilon_{i t}
$$


where $\operatorname{prod}_{i t}$ stands for the natural logarithm of labour productivity for firm $i$ in year $t$, measured as firmlevel added value divided by firm-level hours worked. $H C_{i t}$ is the main explanatory variable and represents the firm-level human capital. The regression also controls for firm characteristics (firm size, worker age composition and the manager-worker wage differential, with managers defined as the top $25 \%$ of earners). $F E_{s t}$ controls for industry-year fixed effects. Both productivity and human capital are measured in threeyear moving averages to reduce the influence of abrupt year-to-year changes and potential measurement error. Standard errors are clustered at the firm level to account for serial correlation of the error term.

29. The human capital variable $H C_{i t}$ captures the percentage share of a particular type of employee in the firm. We focus on the share of high-skilled workers and (high-skilled) STEM workers.

30. The advantage of using this model is that we can interpret the coefficient $\alpha$ as an elasticity ${ }^{14}$ of productivity as a function of the share of workers with a certain characteristic. For example, a value of 1 implies that a 1 percentage point (pp) change in the share of high-skilled workers is correlated with a $1 \%$ increase in productivity, if all other characteristics are kept constant.

31. The disadvantage of this model is that it only put forward correlations and it does not control for so-called simultaneity bias. This bias arises when a certain event simultaneously affects both a firm's productivity and its human capital. A firm might be confronted with a suddenly reduced turnover and therefore reduced labour productivity and will decrease its workforce accordingly. As these layoffs might impact different skill levels differently our model could mistakenly attribute this reduced productivity to the change in the workforce composition. Lebedinski and Vandenberghe (2014) do control for these issues, comparing different methodologies and working with Belgian firm-level data. They conclude that "simultaneity bias is not pronounced in the case of Belgian firms". This implies that the correlations found via our methodology will be closely aligned to the causal impact of human capital on productivity.

32. The results in Table 2 confirm the findings from the descriptive evidence of the previous section. Firms that employ a larger share of high-skilled workers are more productive. In column (1), based on firms in all industries, we find an elasticity of 0.91 (coefficient for Share high-skilled). This implies that increasing the share of high-skilled workers by $1 \mathrm{pp}$ (at the expense of medium-skilled workers) raises productivity by $0.91 \%$. This elasticity decreases to 0.62 when we include interacted variables and control for the share of STEM workers (column 2). The coefficient for high-skilled workers is larger than for lowskilled workers. This implies that replacing a medium-skilled worker by a high-skilled worker has a higher return than replacing a low-skilled worker by a medium-skilled one. We also find a negative value for lowskilled workers, and that highlights the importance to productivity of continued efforts to reduce the share of early leavers from education.

33. In Table 2 column (4) we clearly find a smaller coefficient for high-skilled workers for knowledgeintensive services (KIS) than for manufacturing (column 3) and less knowledge-intensive services (LKIS, column 5). From Figure $7 \mathrm{C}$ we already learned that, for firms in KIS, there are only small differences between frontier and medium performers with respect to the share of high-skilled workers. Given that this share is already very high, most firms in KIS might already have exploited the possible productivity gains stemming from an increase in the skill level of the workforce.

34. This brings us to the coefficient of the squared level of the share of high-skilled workers (High $\times$ high). A negative value indicates that there are decreasing marginal returns from increasing the share of high-skilled workers. For manufacturing (with a high coefficient for Share high - skilled and a coefficient for High $\times$ high that is not significantly different from 0 ) there is still significant potential for productivity gains from increasing the share of high-skilled workers. The complementarity of high-skilled workers and medium-skilled workers is especially pronounced for less knowledge-intensive services. Only in the case

\footnotetext{
${ }^{14}$ Strictly speaking we find semi-elasticities as we study the impact of an absolute change of the percentage of the total firm-level employment of a certain skill level on the relative change of productivity.
} 
of LKIS is the coefficient for High $\times$ low significantly different from 0 and negative. The interpretation is that the productivity gains from increasing the share of high-skilled workers are almost entirely eliminated if the share is increased at the expense of medium-skilled workers.

35. An additional coefficient of interest in Table 2 is the one for Share STEM. Share STEM stands for the share of workers with STEM skills, regardless of whether this is at the low-, medium- or high-skilled level. We find a clear positive and significant coefficient for all industries combined, manufacturing and LKIS. This implies that increasing the share of STEM workers (whilst keeping the overall share of low-, medium- and high-skilled constant) is positive for firm-level productivity. For KIS the coefficient is not significant, which confirms the findings in the previous section (Figure 9C). Possibly most firms in KIS already employ their optimal level of STEM workers, and the STEM worker shortages are predominantly apparent within the manufacturing and LKIS sectors that could still make productivity gains from employing more STEM workers.

Table 2. Human capital and productivity, regression results

\begin{tabular}{|c|c|c|c|c|c|}
\hline & $\begin{array}{c}\text { (1) } \\
\text { All industries } \\
\text { labour prod. }\end{array}$ & $\begin{array}{l}\text { (2) } \\
\text { All industries } \\
\text { labour prod. }\end{array}$ & $\begin{array}{c}\text { (3) } \\
\text { Manufacturing } \\
\text { labour prod. }\end{array}$ & $\begin{array}{c}\text { (4) } \\
\text { KIS } \\
\text { labour prod. }\end{array}$ & $\begin{array}{c}\text { (5) } \\
\text { LKIS } \\
\text { labour prod. }\end{array}$ \\
\hline Share high-skilled & $\begin{array}{l}0.912^{* * *} \\
(0.019)\end{array}$ & $\begin{array}{l}0.621^{* * *} \\
(0.021)\end{array}$ & $\begin{array}{l}0.653^{* * *} \\
(0.048)\end{array}$ & $\begin{array}{c}0.218^{*} \\
(0.093)\end{array}$ & $\begin{array}{l}0.720^{* * *} \\
(0.028)\end{array}$ \\
\hline Share low-skilled & $\begin{array}{c}-0.178^{* * * *} \\
(0.015)\end{array}$ & $\begin{array}{l}-0.310^{* * *+} \\
(0.021)\end{array}$ & $\begin{array}{c}-0.144^{*+* t} \\
(0.045)\end{array}$ & $\begin{array}{c}-0.360^{* * *} \\
(0.093)\end{array}$ & $\begin{array}{c}-0.319^{* * *+} \\
(0.030)\end{array}$ \\
\hline High $\times$ high & & $\begin{array}{c}-0.308^{+* * *} \\
(0.061)\end{array}$ & $\begin{array}{l}-0.045 \\
(0.236)\end{array}$ & $\begin{array}{c}0.208 \\
(0.147)\end{array}$ & $\begin{array}{c}-0.234^{*} \\
(0.101)\end{array}$ \\
\hline High $\times$ low & & $\begin{array}{l}-0.920^{+* * *} \\
(0.114)\end{array}$ & $\begin{array}{c}0.084 \\
(0.276)\end{array}$ & $\begin{array}{l}-0.197 \\
(0.330)\end{array}$ & $\begin{array}{c}-0.871^{\text {**t* }} \\
(0.169)\end{array}$ \\
\hline Share STEM & & $\begin{array}{l}0.227^{+* *+} \\
(0.013)\end{array}$ & $\begin{array}{l}0.273^{+* *+} \\
(0.027)\end{array}$ & $\begin{array}{l}-0.041 \\
(0.027)\end{array}$ & $\begin{array}{l}0.390^{* * *} \\
(0.021)\end{array}$ \\
\hline Additional controls & $\begin{array}{c}\text { age composition, } \\
\text { manager/ worker } \\
\text { wage }\end{array}$ & $\begin{array}{c}\text { age composition, } \\
\text { manager/ worker } \\
\text { wage }\end{array}$ & $\begin{array}{c}\text { age composition, } \\
\text { manager/ worker } \\
\text { wage }\end{array}$ & $\begin{array}{c}\text { age composition, } \\
\text { manager/ worker } \\
\text { wage }\end{array}$ & $\begin{array}{l}\text { age composition, } \\
\text { manager/ worker } \\
\text { wage }\end{array}$ \\
\hline Industry $\times$ year FE & yes & yes & yes & yes & yes \\
\hline Firm size categories & yes & yes & yes & yes & yes \\
\hline R-squared & 0.348 & 0.406 & 0.379 & 0.386 & 0.416 \\
\hline Number of observations & 321688 & 321688 & 65194 & 29312 & 176910 \\
\hline
\end{tabular}

Note: Results for OLS regression model at the firm-level (equation 1). Columns (1) and (2) includes all firms, whereas columns (3), (4) and (5) only include firms in the manufacturing sector, knowledge-intensive services (KIS) and less knowledge-intensive services (LKIS) respectively. The explanatory variables refer to employment shares of worker groups as percentages of total firm-level employment.

Standard errors in parentheses $\left(+p<0.10,{ }^{*} p<0.05,{ }^{* *} p<0.01,{ }^{* \star *} p<0.001\right)$ and clustered at the firm level.

36. Figure 13 now compares the elasticities of productivity as a function of the share of high-skilled workers (Panel A) and the share of STEM workers (panel B) in the form of a graph. We include not only the results from Table 2 but also the results for the same regression specification on only a sub-sample of the data, making a distinction according to the time period (pre-financial crisis, financial crisis and postfinancial crisis) and focusing on large firms. ${ }^{15}$

${ }^{15}$ Large firms are defined as having more than 250 employees. 
37. We learn from Figure 13 that the elasticity for high-skilled workers is becoming smaller over time. From 0.65 for the period $2000-2007$ it declined to 0.54 for the period 2012-2018. The productivity gains from increasing the share of high-skilled workers are therefore diminishing. For STEM workers we find the opposite effect with the elasticity increasing from 0.20 (2000-2007) to $0.26(2012-2018) .{ }^{16}$ STEM workers are becoming ever more important for boosting firm-level productivity. With more widespread digitalisation, we can expect this trend to continue.

38. In Figure 13 we also make a distinction between all firms and large firms on their own for each of the three sectors. Confining our analysis to large firms makes the sample significantly smaller so that the confidence intervals are larger. Nevertheless, we can still conclude that, particularly for the manufacturing sector, the elasticities are higher for large firms compared to all firms combined. This means that not only do large firms benefit more from ICT fixed investment (Dhyne et al. 2020), but large firms also benefit more from human capital investment.

39. We now investigate the impact of STEM workers on firm-level productivity. In Table 3 we include more variables related to the share of (high-skilled) STEM workers within a firm. E.g., Share high skilled (STEM) now represents the share of high-skilled workers within the firm's total group of STEM workers. ${ }^{17}$ Also, after including more STEM variables, the results for Share STEM remain similar to the results from Table 2. The coefficient for Share high-skilled (non-STEM), representing the share of high-skilled workers within the non-STEM workforce, remains similar as well, except for KIS. For KIS the productivity benefits from non-STEM high-skilled workers exceed the benefits from STEM high-skilled workers. For manufacturing and LKIS the benefits from high-skilled STEM workers outweigh the benefits from high-skilled non-STEM workers. Note that adding more high-skilled STEM workers increases both the share of STEM workers overall (Share STEM) and the share of high-skilled STEM workers (Share high - skilled (STEM)).

40. Based on the results from Table 3 we can quantify the impact of skill changes within a firm. In the manufacturing sector, in particular, the potential gains from hiring more STEM workers are significant. Take the example of a manufacturing firm with a workforce of 100 employing 30 STEM workers, ${ }^{18}$ of whom 15 are high-skilled and 15 are medium- or low-skilled. If this firm replaces a low-skilled STEM worker by a high-skilled STEM worker, the firm increases the share of high-skilled workers within its STEM workforce from $50 \%$ to $53.3 \%$ and raises productivity by $\sim 2 \% .{ }^{19}$ The productivity return from replacing a low-skilled non-STEM worker by a high-skilled worker will be significantly smaller at $\sim 0.6 \%{ }^{20}$ If the high-skilled STEM worker replaces a non-STEM worker the gains are even greater. The difference between STEM and nonSTEM if the high-skilled worker replaces a medium-skilled worker is even larger as the coefficient for Share low - skilled (STEM) is not significant.

\footnotetext{
${ }^{16} \mathrm{~A}$ two sample t-test confirms that the elasticity as a function of the share of high-skilled workers and the share of STEM workers is higher during the 2012-2018 period than during the 2002-2007 period with a $p$-value $<0.001$.

17 The sum of the 3 variables Share high-skilled (STEM), Share medium-skilled (STEM) and Share lowskilled (STEM) within a firm therefore equals $100 \%$.

18 The typical share in medium and frontier firms in Figure $9 \mathrm{~A}$.

${ }^{19}$ The percentage point increase is 3.3 times the coefficient for Share high-skilled (STEM) 0.628.

20 If 35 of the 70 non-STEM workers are high-skilled, increasing that number to 36 will only increase Share high skilled (STEM) by 1.4 percentage points, and hence raises productivity by $0.64 \%$, i.e. $1.4 \times 0.351+1.4 \times 0.103$.
} 
Figure 13. Elasticities of productivity differentiated by time period and size of firm

Panel A: Elasticities of productivity as a function of the share of high-skilled workers

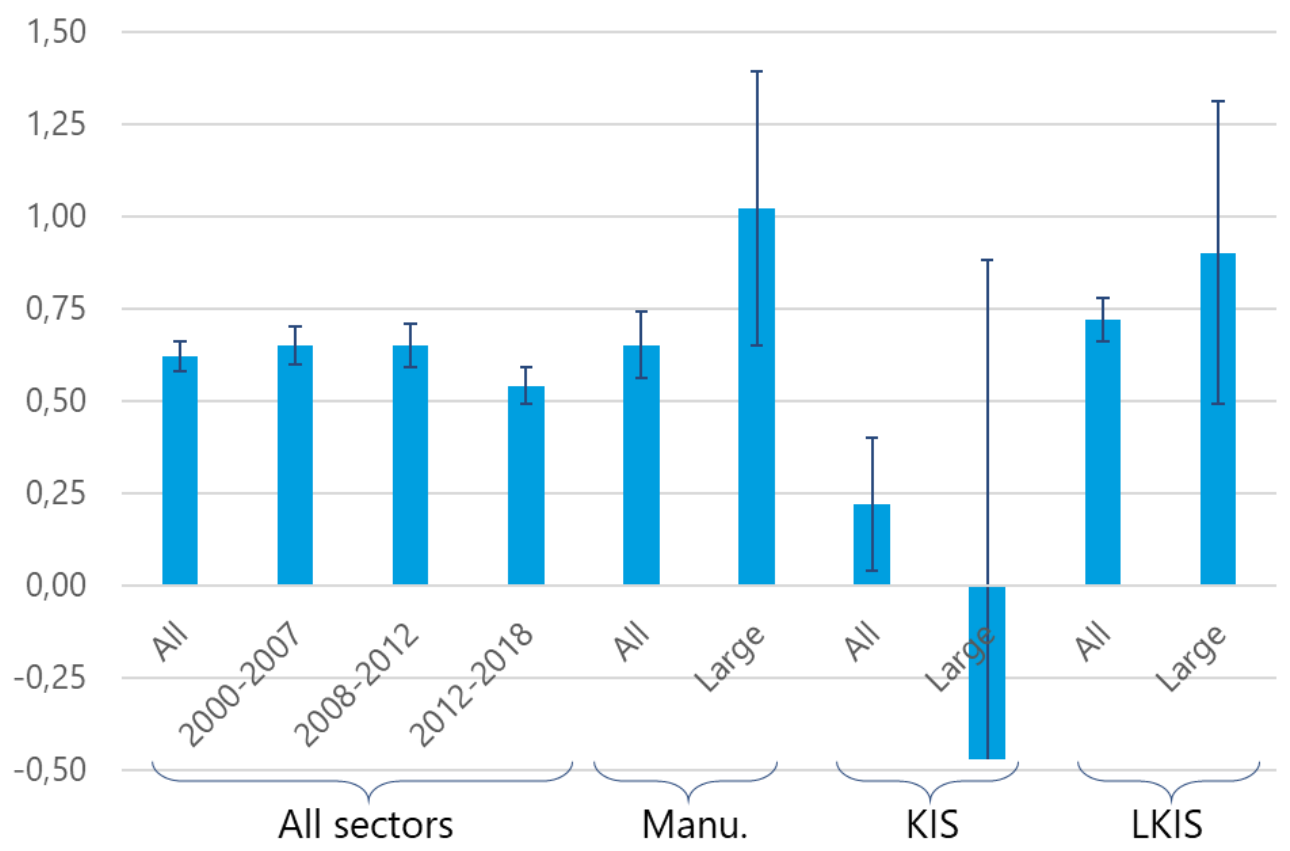

Panel B: Elasticities of productivity as a function of the share of STEM workers

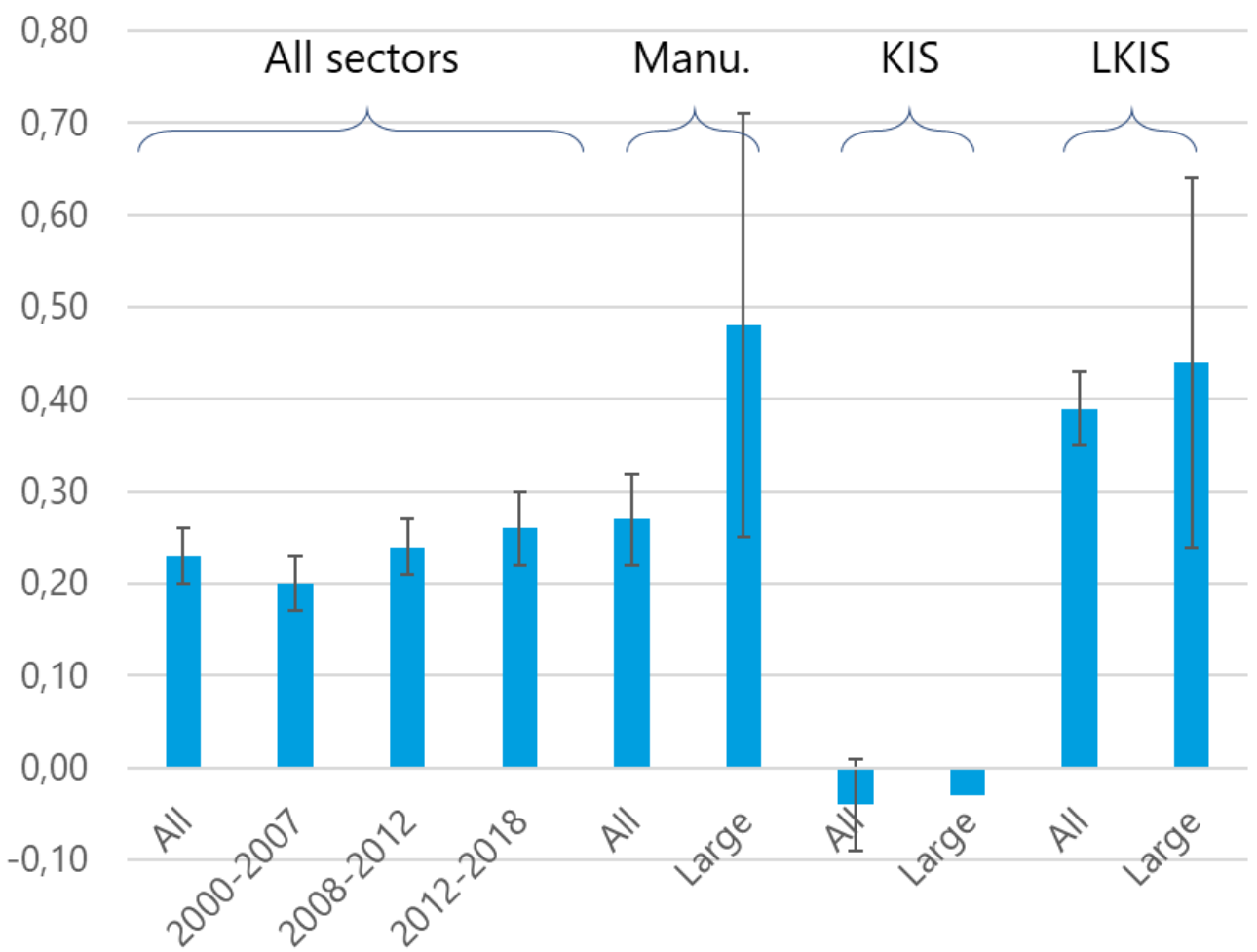

Note: Results for the coefficient for Share high-skilled (Panel A) and Share STEM (Panel B) come from the OLS regression model at the firmlevel (equation 1). The brackets mark the $95 \%$ confidence intervals. The (negative) confidence interval for large firms in KIS is omitted to maintain the clarity of the graph. Large firms are defined as having more than 250 employees.

Source: Authors' calculations based on linked employer-employee data. 
Table 3. STEM human capital and productivity, regression results

\begin{tabular}{|c|c|c|c|c|c|}
\hline & $\begin{array}{c}\text { (1) } \\
\text { All industries } \\
\text { labour prod. }\end{array}$ & $\begin{array}{c}\text { (2) } \\
\text { All industries } \\
\text { labour prod. }\end{array}$ & $\begin{array}{c}\text { (3) } \\
\text { Manufacturing } \\
\text { labour prod. }\end{array}$ & $\begin{array}{c}\text { (4) } \\
\text { KIS } \\
\text { labour prod. }\end{array}$ & $\begin{array}{c}\text { (5) } \\
\text { LKIS } \\
\text { labour prod. }\end{array}$ \\
\hline Share STEM & $\begin{array}{c}0.259^{* * *} \\
(0.0141)\end{array}$ & $\begin{array}{l}0.234^{* * *} \\
(0.0131)\end{array}$ & $\begin{array}{l}0.205^{* *+*} \\
(0.027)\end{array}$ & $\begin{array}{c}-0.026 \\
(0.0367)\end{array}$ & $\begin{array}{l}0.446^{*+*} \\
(0.021)\end{array}$ \\
\hline Share high-skilled (STEM) & & $\begin{array}{l}0.414^{* * *} \\
(0.018)\end{array}$ & $\begin{array}{l}0.628^{* * *} \\
(0.039)\end{array}$ & $\begin{array}{c}0.135+ \\
(0.0704)\end{array}$ & $\begin{array}{l}0.326^{* * *} \\
(0.026)\end{array}$ \\
\hline Share high-skilled (non-STEM) & & $\begin{array}{l}0.605^{* * *} \\
(0.017)\end{array}$ & $\begin{array}{l}0.351^{*+*+} \\
(0.033)\end{array}$ & $\begin{array}{l}0.680^{*+*} \\
(0.081)\end{array}$ & $\begin{array}{l}0.792^{*+*} \\
(0.026)\end{array}$ \\
\hline Share low-skilled (STEM) & & $\begin{array}{c}0.004 \\
(0.014)\end{array}$ & $\begin{array}{c}0.002 \\
(0.032)\end{array}$ & $\begin{array}{l}-0.037 \\
(0.054)\end{array}$ & $\begin{array}{c}0.003 \\
(0.0196)\end{array}$ \\
\hline Share low-skilled (non-STEM) & & $\begin{array}{l}-0.162^{* * *} \\
(0.016)\end{array}$ & $\begin{array}{l}-0.103^{* * *} \\
(0.029)\end{array}$ & $\begin{array}{l}-0.135^{*} \\
(0.062)\end{array}$ & $\begin{array}{l}-0.184^{*+*} \\
(0.025)\end{array}$ \\
\hline High $\times$ high $($ STEM) & & $\begin{array}{c}-0.280^{+* * *} \\
(0.039)\end{array}$ & $\begin{array}{l}-0.448^{*+*} \\
(0.122)\end{array}$ & $\begin{array}{c}0.056 \\
(0.078)\end{array}$ & $\begin{array}{l}-0.200^{+*+*} \\
(0.056)\end{array}$ \\
\hline High $\times$ low (STEM) & & $\begin{array}{l}0.205^{*} \\
(0.079)\end{array}$ & $\begin{array}{c}0.156 \\
(0.182)\end{array}$ & $\begin{array}{c}0.002 \\
(0.247)\end{array}$ & $\begin{array}{l}0.202+ \\
(0.107)\end{array}$ \\
\hline High $\times$ high (non-STEM) & & $\begin{array}{l}-0.293^{* * *} \\
(0.057)\end{array}$ & $\begin{array}{l}-0.253^{+} \\
(0.150)\end{array}$ & $\begin{array}{l}-0.268^{*} \\
(0.116)\end{array}$ & $\begin{array}{l}-0.151 \\
(0.098)\end{array}$ \\
\hline High $\times$ low (non-STEM) & & $\begin{array}{l}-0.973^{* * *} \\
(0.086)\end{array}$ & $\begin{array}{l}-0.229 \\
(0.166)\end{array}$ & $\begin{array}{c}0.031 \\
(0.259)\end{array}$ & $\begin{array}{l}-0.866^{* *+*} \\
(0.139)\end{array}$ \\
\hline Additional controls & no & no & no & no & no \\
\hline Industry x year FE & yes & yes & yes & yes & yes \\
\hline Firm size categories & yes & yes & yes & yes & yes \\
\hline R-squared & 0.231 & 0.357 & 0.360 & 0.204 & 0.371 \\
\hline Number of observations & 321688 & 321688 & 65194 & 29312 & 176910 \\
\hline
\end{tabular}

Note: Results for OLS regression model at the firm-level (equation 1). Columns (1) and (2) include all firms, whereas columns (3), (4) and (5) only include firms in the manufacturing sector, knowledge-intensive services (KIS) and less knowledge-intensive services (LKIS) respectively. Share STEM refers to the employment share of ICT workers as a percentage of firm-level employment.

Standard errors in parentheses $\left(+p<0.10,{ }^{*} p<0.05,{ }^{* *} p<0.01,{ }^{* * *} p<0.001\right)$ and clustered at the firm-level.

\section{Discussion and Conclusion}

41. A return to productivity growth will make the economic challenges that lie ahead (COVID-19 recovery, climate change, ageing population, etc.) much more manageable. Governments rightly put the emphasis on infrastructure, research, innovation and digitalisation as the means to increase productivity. However, the importance of human capital in restoring productivity growth must not be underestimated. The need for an increased supply of high-skilled workers to boost productivity should not be forgotten. Without an extended supply of human capital, the efforts could simply result in higher wages for the most skilled rather than true innovation and accompanying productivity growth.

42. In this paper we use employer - employee linked data covering the full Belgian private sector over a period of almost 20 years. We can confirm that firm-level productivity and the skills profile of a firm's 
workforce go hand in hand. Frontier firms (i.e. the $10 \%$ most productive firms within a sector) are not only widening the productivity gap in relation to other firms but are also increasing the skills gap. On average, the share of high-skilled workers in a frontier firm is currently almost 10 percentage points higher than in a medium performer and 20 percentage points higher than in a laggard firm. The larger share of high-skilled workers in frontier firms is mainly offset by a smaller share of low-skilled workers, i.e. workers who did not complete their secondary education. Close to $10 \%$ of the Belgian population aged 18-25 years do not hold a secondary education certificate and are not in further training or education. Job opportunities for the lowest-skilled workers are mainly found in the least productive firms.

43. Using regression analysis, we can control for a wide range of firm-level characteristics. We find elasticities of productivity as a function of the share of high-skilled workers of 0.20 (knowledge-intensive services), 0.60 (manufacturing) and 0.70 (less knowledge-intensive services). This implies that increasing the share of high-skilled workers by 10 percentage points is correlated with an increase in productivity of between $2 \%$ and $7 \%$. This elasticity as a function of the share of high-skilled workers has decreased over time for all sectors combined, declining from 0.65 for the period 2000-2007 to 0.55 for the period 20122018. This is in line with the decreasing marginal returns from increasing the share of high-skilled workers.

44. To deliver on the growing need for automation and digitalisation, there is also a need for workers with STEM skills. Although Belgium performs relatively well with respect to tertiary education graduates, its performance is poorer with respect to STEM graduates. For the manufacturing industry and the less knowledge-intensive services we do observe a clear, positive link between productivity and the share of STEM workers. For knowledge-intensive services, only the laggard firms employ a smaller percentage of STEM workers, and we see little difference between frontier firms and medium performers.

45. For STEM workers (high-, medium- and low-skilled) we find elasticities of 0.25 (manufacturing) and 0.40 (less knowledge-intensive services). But more importantly, unlike the elasticity for high-skilled workers that decreases over time, the elasticity for STEM workers is increasing. The average elasticity across all sectors has risen from $0.20(2000-2007)$ to 0.26 (2012-2018). This could be linked to the growing importance of (ICT) technology.

46. Increasing the share of high-skilled STEM workers is correlated with significantly larger productivity gains than for STEM workers in general and high-skilled non-STEM workers. For a typical manufacturing firm, a 1 percentage point increase in the share of high-skilled STEM workers generates a productivity gain of $\sim 2 \%$, or approx. 3 to 4 times more than the gains from a 1 percentage point increase in the share of high-skilled non-STEM workers. The difficulties that Belgian firms experience in recruiting specialist ICT skills are therefore likely to have a significantly negative impact on productivity.

47. Considering the results presented above and bearing in mind that they mostly reflect past correlations, we can still draw some policy recommendations from this empirical exercise. The main one is that policies designed to promote the adoption of the latest technologies and business practices within firms can only lead to sustainable productivity gains if they are combined with measures to increase the supply and mobility of human (STEM) capital. Without a proper supply of skills, firms will not be able to reap the full benefits of the digital revolution.

48. We also briefly touch on the link between the share of foreign workers and productivity. Only in the case of knowledge-intensive services is the share of foreign workers positively correlated with productivity. The most productive service firms generally rely on highly educated foreigners with specific competencies. As it remains uncertain if and when global mobility of high-skilled workers will recover in the wake of the COVID-19 pandemic, the potential shortage of high-skilled workers could have long-lasting (negative) effects on the productivity of some knowledge-intensive service firms. 


\section{References}

Akcigit, U., \& Ates, S. T. (2019), "What Happened to US Business Dynamism?”, (No. w25756), National Bureau of Economic Research.

Akcigit, U., Pearce, J. G., \& Prato, M. (2020), "Tapping into talent: Coupling education and innovation policies for economic growth", (No. w27862), National Bureau of Economic Research.

Autor, D., Dorn, D., Katz, L. F., Patterson, C., \& Van Reenen, J. (2020), "The fall of the labor share and the rise of superstar firms", The Quarterly Journal of Economics, 135(2), 645-709.

Bijnens, G., \& Konings, J. (2020), "Declining business dynamism in Belgium”, Small Business Economics, 54(4), 1201-1239.

Brynjolfsson, E., Rock, D., \& Syverson, C. (2021), "The productivity J-curve: How intangibles complement general purpose technologies", American Economic Journal: Macroeconomics, 13(1), 333-72.

Calvino, F., Criscuolo, C., \& Verlhac, R. (2020), "Declining business dynamism: Structural and policy determinants", OECD Science, Technology and Industry Policy Papers, No. 94, OECD Publishing, Paris.

Criscuolo, C., et al. (2021), "The firm-level link between productivity dispersion and wage inequality: A symptom of low job mobility?", OECD Economics Department Working Papers, No. 1656, OECD Publishing, Paris.

Criscuolo, C., Gal, P., Leidecker T., \& Nicoletti, G. (2021), The Human Side of Productivity: Uncovering the role of skills, managers and diversity, Report from the OECD Global Forum on Productivity, forthcoming.

De Loecker, J., Eeckhout, J., \& Unger, G. (2020), "The rise of market power and the macroeconomic implications", The Quarterly Journal of Economics, 135(2), 561-644.

De Ridder, M. (2020), "Market Power and Innovation in the Intangible Economy," Cambridge Working Papers in Economics 1931, Faculty of Economics, University of Cambridge.

Dhyne, E., Konings, J., Van den Bosch, J., \& Vanormelingen, S. (2020), The Return on Information Technology: Who Benefits Most?. Information Systems Research.

Fernald, J. G., \& Jones, C. I. (2014), "The future of US economic growth", American economic review, 104(5), 44-49.

Gal, P., Nicoletti, G., Renault, T., Sorbe, S., \& Timiliotis, C. (2019), "Digitalisation and productivity: In search of the holy grail-Firm-level empirical evidence from EU countries", OECD Economics Department Working Papers, No. 1533, OECD Publishing, Paris.

Jäger, K. (2017), EU KLEMS growth and productivity accounts 2016 release (Description of Methodology and General Notes), EU KLEMS.

Kampelmann, S., \& Rycx, F. (2012), "The impact of educational mismatch on firm productivity: Evidence from linked panel data", Economics of Education Review, 31(6), 918-931.

Lebedinski, L., \& Vandenberghe, V. (2014), “Assessing education's contribution to productivity using 
firm-level evidence", International Journal of Manpower.

Lens, D., Marx, I., \& Mussche, N. (2021), "De effecten van de COVID-19 pandemie op arbeidsmigratie en-mobiliteit", COVIVAT Policy Paper No. 8.

Maldonado, J. E., \& De Witte, K. (2020), "The effect of school closures on standardised student test outcomes”, KU Leuven Department of Economics Discussion Paper DPS20, 17.

OECD (2019), Compendium of Productivity Indicators 2019, OECD Publishing, Paris.

Romer, P. M. (2000), "Should the government subsidize supply or demand in the market for scientists and engineers?", Innovation policy and the economy, 1, 221-252.

Saks, Y. (2021), "Wage differentiation in Belgium according to SILC data", National Bank of Belgium Economic Review, 2021.

Schultz, T. W. (1961), "Investment in human capital", The American Economic Review, 51(1), 1-17.

Tan, E. (2014), "Human capital theory: A holistic criticism", Review of Educational Research, 84(3), 411445.

Zimmer, H. (2012), "Labour market mismatches", National Bank of Belgium Economic Review, 2012(ii), $55-68$ 


\section{Annex A. Industry classification}

Table A.1. Mapping of NACE 2-digit industries into different classifications

\begin{tabular}{|c|c|c|c|}
\hline NACE 2-digit & $\begin{array}{l}\text { OECD STAN A38 } \\
\text { grouping }\end{array}$ & Category & ICT intensive \\
\hline $10-12$ & $\begin{array}{l}\text { Food products, } \\
\text { beverages and tobacco } \\
{[\mathrm{CA}]}\end{array}$ & Manufacturing & \\
\hline $13-15$ & $\begin{array}{l}\text { Textiles, wearing } \\
\text { apparel, leather and } \\
\text { related products [CB] }\end{array}$ & Manufacturing & \\
\hline $16-18$ & $\begin{array}{l}\text { Wood and paper } \\
\text { products, and printing } \\
\text { [CC] }\end{array}$ & Manufacturing & \\
\hline 19 & $\begin{array}{l}\text { Coke and refined } \\
\text { petroleum products } \\
{[C D]}\end{array}$ & Manufacturing & Yes \\
\hline 20 & $\begin{array}{l}\text { Chemicals and } \\
\text { chemical products [CE] }\end{array}$ & Manufacturing & Yes \\
\hline 21 & $\begin{array}{l}\text { Basic pharmaceutical } \\
\text { products and } \\
\text { pharmaceutical } \\
\text { preparations [CF] }\end{array}$ & Manufacturing & Yes \\
\hline $22-23$ & $\begin{array}{l}\text { Rubber and plastics } \\
\text { products, and other } \\
\text { non-metallic mineral } \\
\text { products [CG] }\end{array}$ & Manufacturing & \\
\hline $24-25$ & $\begin{array}{l}\text { Basic metals and } \\
\text { fabricated metal } \\
\text { products, except } \\
\text { machinery and } \\
\text { equipment }[\mathrm{CH}]\end{array}$ & Manufacturing & \\
\hline 26 & $\begin{array}{l}\text { Computer, electronic } \\
\text { and optical products } \\
{[\mathrm{Cl}]}\end{array}$ & Manufacturing & \\
\hline 27 & $\begin{array}{l}\text { Electrical equipment } \\
{[\mathrm{CJ}]}\end{array}$ & Manufacturing & \\
\hline 28 & $\begin{array}{l}\text { Machinery and } \\
\text { equipment n.e.c. [CK] }\end{array}$ & Manufacturing & Yes \\
\hline $29-30$ & $\begin{array}{l}\text { Transport equipment } \\
{[\mathrm{CL}]}\end{array}$ & Manufacturing & \\
\hline $31-33$ & $\begin{array}{l}\text { Furniture; other } \\
\text { manufacturing; repair } \\
\text { and installation of } \\
\text { machinery and } \\
\text { equipment [CM] }\end{array}$ & Manufacturing & \\
\hline 35 & $\begin{array}{l}\text { Electricity, gas, steam } \\
\text { and air conditioning } \\
\text { supply [D] }\end{array}$ & & Yes \\
\hline $36-39$ & $\begin{array}{l}\text { Water supply; } \\
\text { sewerage, waste }\end{array}$ & & Yes \\
\hline
\end{tabular}




\begin{tabular}{|c|c|c|c|}
\hline & $\begin{array}{l}\text { management and } \\
\text { remediation activities } \\
{[\text { E] }}\end{array}$ & & \\
\hline $41-43$ & Construction [F] & & \\
\hline $45-47$ & $\begin{array}{l}\text { Wholesale and retail } \\
\text { trade, repair of motor } \\
\text { vehicles and } \\
\text { motorcycles [G] }\end{array}$ & LKIS & Yes \\
\hline $49-53$ & $\begin{array}{l}\text { Transportation and } \\
\text { storage }[\mathrm{H}]\end{array}$ & LKIS & \\
\hline $55-56$ & $\begin{array}{l}\text { Accommodation and } \\
\text { food service activities } \\
\text { [I] }\end{array}$ & LKIS & \\
\hline $58-60$ & $\begin{array}{l}\text { Publishing, audiovisual } \\
\text { and broadcasting } \\
\text { activities [JA] }\end{array}$ & LKIS & Yes \\
\hline 61 & $\begin{array}{l}\text { Telecommunications } \\
\text { [JB] }\end{array}$ & KIS & Yes \\
\hline $62-63$ & $\begin{array}{l}\text { IT and other } \\
\text { information services } \\
{[\mathrm{JC}]}\end{array}$ & KIS & Yes \\
\hline $64-66$ & $\begin{array}{l}\text { Financial and insurance } \\
\text { activities }[\mathrm{K}]\end{array}$ & KIS & \\
\hline 68 & Real estate activities [L] & LKIS & \\
\hline 69-71 & $\begin{array}{l}\text { Legal and accounting } \\
\text { activities, etc. [MA] }\end{array}$ & KIS & \\
\hline 72 & $\begin{array}{l}\text { Scientific research and } \\
\text { development [MB] }\end{array}$ & KIS & \\
\hline 73-75 & $\begin{array}{l}\text { Advertising and market } \\
\text { research; other } \\
\text { professional, scientific } \\
\text { and technical activities } \\
\text { [MC] }\end{array}$ & KIS & Yes \\
\hline $77-82$ & $\begin{array}{l}\text { Administrative and } \\
\text { support service } \\
\text { activities }\end{array}$ & LKIS & Yes \\
\hline
\end{tabular}

Note: KIS = Knowledge Intensive Service, LKIS = Less Knowledge Intensive Service 


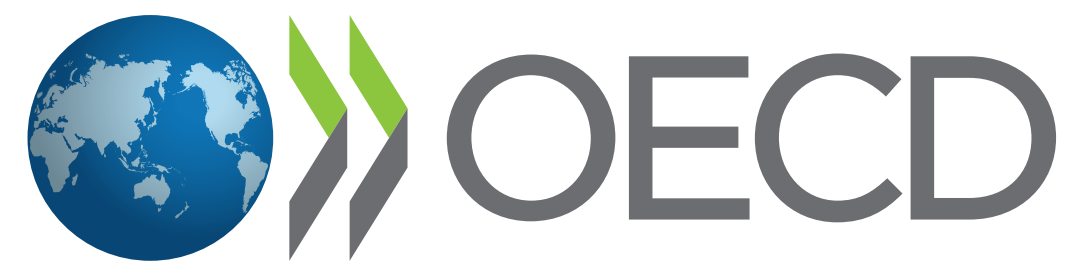

BETTER POLICIES FOR BETTER LIVES 